\title{
REVISED The sedentary (r)evolution: Have we lost our metabolic
}

\section{flexibility? [version 2; peer review: 2 approved, 1 approved}

\section{with reservations]}

\author{
Jens Freese1, Rainer Johannes Klement (iD2, Begoña Ruiz-Núñez³, \\ Sebastian Schwarz ${ }^{4}$, Helmut Lötzerich ${ }^{1}$
}

1'Institute of Outdoor Sports and Environmental Science, German Sports University Cologne, Cologne, 50933, Germany
2Department of Radiotherapy and Radiation Oncology, Leopoldina Hospital Schweinfurt, Schweinfurt, 97422, Germany
3Laboratory Medicine, University of Groningen, University Medical Center Groningen, Groningen, 9713, The Netherlands
${ }^{4}$ University College Physiotherapy Thim van der Laan,, Landquart, 7302, Switzerland

V2 First published: 02 Oct $2017,6: 1787$

https://doi.org/10.12688/f1000research.12724.1

Latest published: 02 Feb 2018, 6:1787

https://doi.org/10.12688/f1000research.12724.2

\section{Abstract}

During the course of evolution, up until the agricultural revolution, environmental fluctuations forced the human species to develop a flexible metabolism in order to adapt its energy needs to various climate, seasonal and vegetation conditions. Metabolic flexibility safeguarded human survival independent of food availability. In modern times, humans switched their primal lifestyle towards a constant availability of energy-dense, yet often nutrient-deficient, foods, persistent psycho-emotional stressors and a lack of exercise. As a result, humans progressively gain metabolic disorders, such as the metabolic syndrome, type 2 diabetes, non-alcoholic fatty liver disease, certain types of cancer, cardiovascular disease and Alzheimer's disease, wherever the sedentary lifestyle spreads in the world. For more than 2.5 million years, our capability to store fat for times of food shortage was an outstanding survival advantage. Nowadays, the same survival strategy in a completely altered surrounding is responsible for a constant accumulation of body fat. In this article, we argue that the metabolic disease epidemic is largely based on a deficit in metabolic flexibility. We hypothesize that the modern energetic inflexibility, typically displayed by symptoms of neuroglycopenia, can be reversed by re-cultivating suppressed metabolic programs, which became obsolete in an affluent environment, particularly the ability to easily switch to ketone body and fat oxidation. In a simplified model, the basic metabolic programs of humans' primal hunter-gatherer lifestyle are opposed to the current sedentary lifestyle. Those metabolic programs, which are chronically neglected in modern surroundings, are identified and conclusions for the prevention of chronic metabolic diseases are drawn.

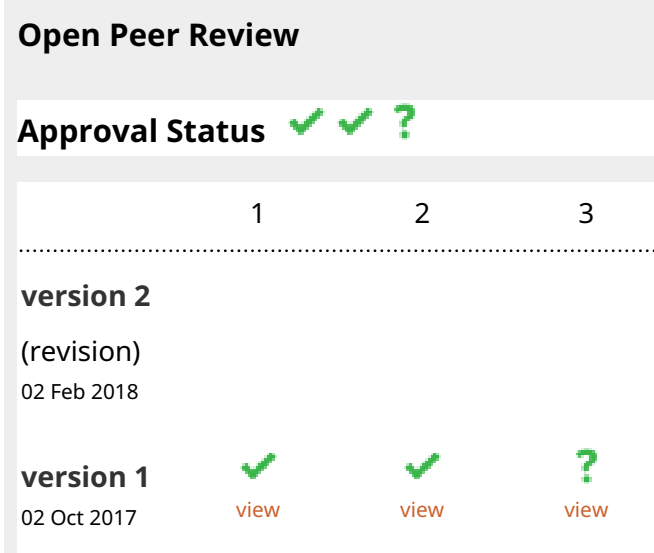

1. Umesh Yadav, Central University of Gujarat,

Gandhinagar, India

Johnna F. Varghese, Central University of

Gujarat, Gandhinagar, India

2. Johannes Coy, Tavartis GmbH, Hainburg, Germany

3. Shuzo Kumagai, Kyushu University, Kasuga City, Japan

Any reports and responses or comments on the article can be found at the end of the article. 
Keywords

Western diseases, Evolution, Hunter-Gatherer Lifestyle, Sedentary

Lifestyle, Metabolic flexibility

Corresponding author: Jens Freese (info@dr-freese.com)

Author roles: Freese J: Writing - Original Draft Preparation; Klement RJ: Writing - Review \& Editing; Ruiz-Núñez B: Writing - Review \& Editing; Schwarz S: Writing - Review \& Editing; Lötzerich H: Supervision

Competing interests: No competing interests were disclosed.

Grant information: The author(s) declared that no grants were involved in supporting this work.

Copyright: @ 2018 Freese J et al. This is an open access article distributed under the terms of the Creative Commons Attribution License, which permits unrestricted use, distribution, and reproduction in any medium, provided the original work is properly cited.

How to cite this article: Freese J, Klement RJ, Ruiz-Núñez B et al. The sedentary (r)evolution: Have we lost our metabolic flexibility? [version 2; peer review: 2 approved, 1 approved with reservations] F1000Research 2018, 6:1787

https://doi.org/10.12688/f1000research.12724.2

First published: 02 Oct 2017, 6:1787 https://doi.org/10.12688/f1000research.12724.1 


\section{REVISED Amendments from Version 1}

1. We have removed some redundant text from the first subsection "Modern habitat: A life in mental stress and physical rest" in order to make the storyline and transition to the following subsections more concise. We have also added a total of five new references that provide additional confirmation of our hypothesis that reverting the sedentary lifestyle induces holistic beneficial metabolic effects

2. We have moved parts from the "Survival of the most flexible" section into the "It's all about survival: Why evolution shaped metabolic flexibility"' section, and also joined both sections together to better connect the lines of reasoning provided in them. We have also re-structured and shortened the section on the uricase mutation in order to make our argumentation more comprehensible.

3. We have rephrased some terms

See referee reports

Charles Darwin: "It is not the strongest of the species that survives, nor the most intelligent, but the one most responsive to change."

\section{Introduction}

During the longest time of Homo sapiens' existence, approximately $99.5 \%$ or 84.000 generations ${ }^{1-3}$, humans' daily survival was shaped by adaptation to a widespread range of different food sources (biodiversity), abundant daily exercise frequently under fasting conditions (foraging behavior), as well as unpredictable food supply (intermittent fasting), depending on the daily foraging success. Consequently, in the course of evolution, environmental stress forced the human species to develop an extraordinary flexible metabolism with multiple programs to guarantee energy equilibrium. Lipolysis, proteolysis, gluconeogenesis, ketone bodies and muscle-derived lactate as alternative energy substrates for cerebral neurons, provide examples by which natural selection tailored humans to buffer fluctuations in energy supply.

Until the Agricultural revolution around 12.000-10.000 BC, when humans began to store food on a larger scale for periods of shortage, survival would have depended on the adaption of energy needs to various climate, seasonal and vegetation conditions. Metabolic flexibility, optimized in millions of years of adaptation to environmental stimuli, safeguarded human survival independent of food disposability ${ }^{5,6}$. Due to an overflow of energy in modern times, humans have inevitably modified many evolutionary-based behavior patterns. As an example, when the body is threatened by energy depletion, hunger normally activates foraging behavior as a prioritized drive in both wild animals and hunter-gatherers, in order to anticipate new food resources ${ }^{7,8}$. Nowadays, hunting and gathering need only a few steps into the kitchen or a short drive to the local food store, which implies substantial energy intake by no or less energy expenditure of the locomotor system ${ }^{9-11}$.

In an evolutionary context, humans switched their primal lifestyle towards a plethora of energy-dense foods, persistent psycho-emotional stressors and a dramatic lack of exercise in record time. As a result of this ultra-rapid metamorphosis, humans progressively present metabolic disorders, such as the metabolic syndrome, type 2 diabetes (T2D), non-alcoholic fatty liver disease, certain types of cancer, cardiovascular disease and Alzheimer's disease, wherever the sedentary lifestyle spreads in the world ${ }^{12-17}$. For more than 2.5 million years, our metabolic adaptation to seasonal food availability was considered to be an outstanding survival advantage. Nowadays, the same survival strategy in a completely altered surrounding is responsible for a constant body fat accumulation for periods of food deficiency, which will, however, very likely not appear again.

In this article, we argue that the strong increase of diseases related to metabolic abnormalities is largely based on a deficit in metabolic flexibility, a term initially stated by Kelley and Mandarino $^{18}$, which describes the way human physiology is adapted to alternate between lipid and carbohydrate fuels to cope with discontinuities of energy disposability in the environment. Here, we conceive this concept not only in a cellular but also rather systemic intention, and hypothesize that the modern energetic inflexibility, typically displayed by symptoms of neuroglycopenia, may be reversed by recultivation of suppressed metabolic programs, now obsolete in an affluent environment. In a model of predominant flux of energetic substrates between organs, the basic metabolic programs of humans' primal hunter-gatherer lifestyle are opposed to the current sedentary lifestyle (see Figure 1 and Figure 2). In particular, we suggest that those metabolic programs relying on efficient fatty acid and ketone body oxidation are most of the time shut off in the modern lifestyle and have to be reintegrated in order to overcome the obesity epidemic - widely known as the breeding ground for most of the Western diseases (WD) ${ }^{19-22}$.

\section{Survival of the most flexible}

Homo sapiens: Adapted to scarcity rather than affluence

Evolution seems to have shaped the human metabolic system for ancient times of frequent energy deficiency rather than the present opulence, which entails adverse consequences, such as hyperglycemia, hyperinsulinemia, dyslipidemia and a chronic proinflammatory state induced by, among other things, accumulating visceral body fat ${ }^{21,23-26}$. Hunger seems an adaptive response to food deprivation that involves neuroendocrine changes to motivate and enable food-seeking behavior ${ }^{27}$. If evolution would not have developed a basic need of hunger-induced motivation for voluntary exercise in correspondence with energy allocation to the locomotor system, Homo sapiens would have become extinct ${ }^{7,28}$. Accordingly, if humans' physical integrity would depend on a continuous ingestion of foods, humankind would not have been able to withstand climate changes, seasonal fluctuations, migration into different vegetation zones, physical conflicts with other hominoid groups, infectious diseases, and intoxications of rotten or dangerous food sources.

\section{It's all about survival: Why evolution shaped metabolic flexibility}

Anthropologic evidence suggests that, in the course of humanization, humans' brain size increased at the expense of a 


\section{HUNTER GATHERER LIFESTYLE}

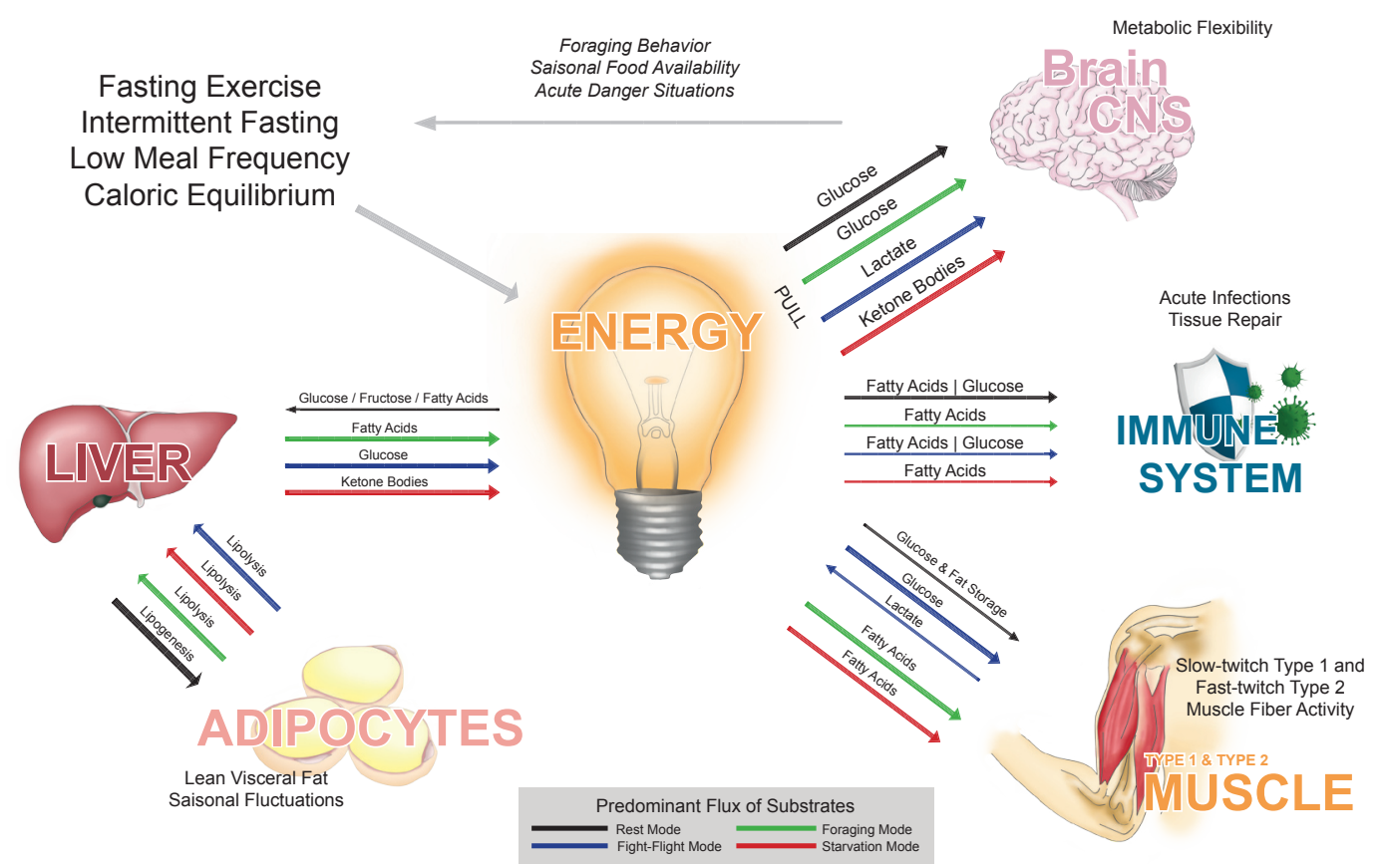

Figure 1. Metabolic flexibility in the hunter-gatherer lifestyle. The brain orchestrates its energy needs by either "pulling" energy from storage organs (from inside the body) in the daily foraging mode, in the short-term fight-flight mode or during long-term hunger in the starvation mode. If food is available, the brain is supplied with energy substrates through a "push" of nutrients (from outside the body) in the rest mode. If all programs are activated occasionally, the metabolic system holds the energetic equilibrium and body weight remains stable.

\section{SEDENTARY LIFESTYLE}

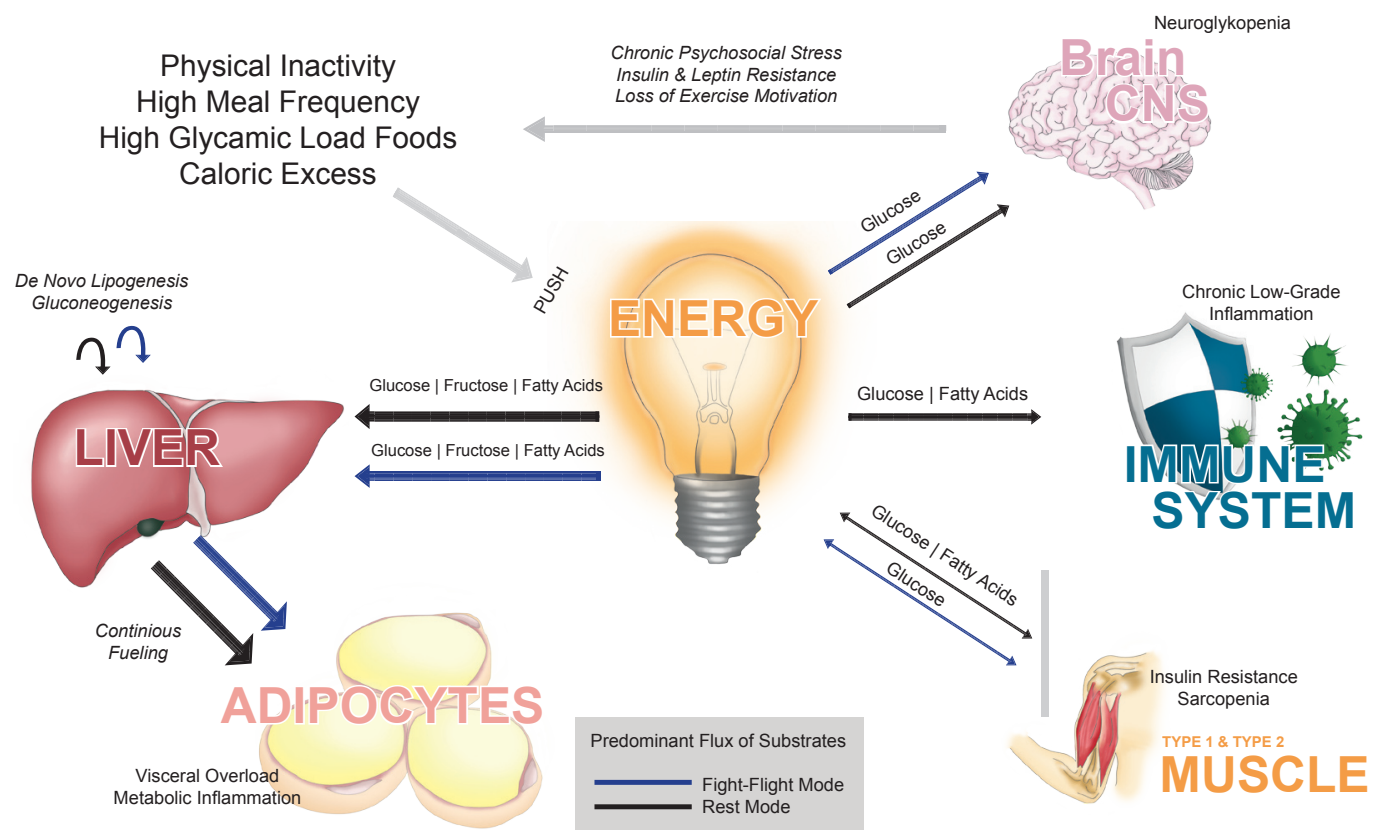

Figure 2. Metabolic inflexibility in the sedentary lifestyle. The "brain pull" (energy allocation from storage organs to the central nervous system) is compromised by "pushing" energy-rich nutrients into the metabolic system continuously. As a consequence, the foraging and starvation modes are both permanently unattended, which leads to a constant fueling of adipocytes, and in the long run to lipotoxicity, sarcopenia, low-grade inflammation and all associated metabolic diseases. 
shorter gut $^{29,30}$. Presumably, humans found more energetically efficient and brain building nutrients ${ }^{31,32}$. In this regard, a long intestine became obsolete with the advantage to expend less energy on digestion, which allows energy distribution to a growing, energetically more demanding brain and the immune system $^{30,33,34}$. When ATP-levels of neurons decrease, the provision of energy to the brain enjoys a privilege, due to limited storing options in cerebral tissues. As a consequence, metabolism must favor an ongoing energy supply to the brain in any kind of situation $^{35-37}$. It is not by coincidence that glucose is the first macronutrient absorbed in the small intestine. Although hypothetical, this fact could underline the rarity of sugar in ancient times. At any rate, cerebral neurons usually favor glucose as their primary energy substrate. However, they are capable of either utilizing ketone bodies from visceral fat cells in starvation periods $^{33,38,39}$ or muscle cell-derived lactate in intense activity (see below). Ketone bodies are the major alternative fuel source for the brain, providing approximately one third of its energy requirements after only four days of very low carbohydrate intake $^{40}$. Ketone utilization is thereby increased in proportion to ketone body blood concentrations and inversely related to the brain's glucose utilization. One mechanism seems to involve a downregulation of glycolysis in astrocytes, which sit between neurons and the vasculature, in this way securing a steady glucose supply to neurons ${ }^{41}$. Interestingly, astroglia and neurons seem to be capable of producing ketone bodies by themselves under conditions of increased AMPK activation, such as hypoxia or hypoglycemia ${ }^{42}$.

In this context, the selfish brain clinical research group (Lübeck, Germany) differentiates between ingestive and allocative behavior (see Figure 1 and Figure 2). In other words, if a human being's brain is adapted to satisfy its energy demands by ingesting high-glycemic dense nutrients (push-principle), it forfeits the ability to allocate (pull-principle) substrates from peripheral storage organs, i.e. glucose and ketone bodies from the liver, free fatty acids from adipocytes and lactate from skeletal muscles $33,37,38,43,44$. Instead, in affluent, sedentary conditions highglycemic load foods are continuously pushed into the metabolic system (see Figure 2), promoting ongoing ingestive behavior, followed by insulin and leptin resistance in the long run. Constant food availability and physical rest accompanied by chronic psychosocial stress insidiously impairs allocative behavior, leading to overnutrition, caloric excess and a persistent fueling of adipocytes. As described, such metabolic inflexible individuals often perceive hypoglycemia (neuroglycopenia), answered by further food intake - the beginning of a vicious circle.

\section{The evolution of obesity: From thrifty genes to uricase mutation}

Storing excessive calories as fat in affluent times is an existential meaningful adaptation in the context of food shortages. Based on this hypothesis, which has been discussed controversial in the field of anthropology, the geneticist James Neel postulated in 1962 his much-cited thrifty gene hypothesis, which states that genes have been positively selected for efficient intake and utilization of food - good for hunter-gatherers in a feast/famine environment, bad for modern people in a world of plenty. In his field studies on Yanomami Indians of the Amazon region, Neel observed that individuals were completely free of overweight and $\mathrm{T} 2 \mathrm{D}^{45-47}$. In contrast, the incidence of T2D in Western industrial countries is at an alarming status ${ }^{15,48}$. Obviously, people currently face a dramatic mismatch between their genetic heritage and today's sedentary lifestyle.

Proponents of Neel's approach consider recurring famines as the driving force for the natural selection of thrifty genes ${ }^{9,49,50}$. Neel proposed that muscles become insulin resistant in a metabolic starvation program to maintain high glucose levels for the central nervous system, while lipolysis is upregulated to provide fatty acids for muscles and ketone bodies for the brain. Speakman challenged this hypothesis later on ${ }^{51}$ with the counter-argument that if overweight would have been so beneficial in the past, there wouldn't exist so many slim people nowadays. He opposed the so-called predation release hypothesis and blamed the loss of natural predators for the obesity epidemic, which were forced back around two million years ago by the development of social behavior, weapons, and fire ${ }^{47,51}$. Furthermore, Berbesque et $a l .{ }^{52}$ found no evidence for assuming that Paleolithic hunter-gatherers would have frequently encountered serious famine conditions, and argued that a cultural or genetic adaption to strive for the most energy-dense foods and to consume them as quick as possible rather than storing them could be a better alternative to the thrift gene hypothesis for explaining the adverse consequences of today's affluent environments.

However, the hypothesis of Neel gained new support through the discovery of a mutation in the uricase gene which occurred 13-17 million years ago, when human ancestors were still great apes and living conditions became colder ${ }^{53}$. Uricase degrades uric acid, which is produced by the breakdown of DNA substances from food or the body's own cells ${ }^{54}$. Uric acid in turn facilitates conversion of fructose into fat stores. Thus, as winter periods became dry and cool in the middle Miocene (approximately 15 million years ago) Hominoids would have become able to better metabolize fructose into fat. However, a survival advantage in the past has now become a curse. Since the invention of the enzymatic extraction of fructose from corn in the 1980 s, refined fructose is attached to most industrial food products, especially sugarsweetened beverages ${ }^{55,56}$. Contrary to Paleolithic times, no winter or dry period provides a degreasing any longer. Apparently, the human metabolic equilibrium seems to be literally depending on differences in food availability, which implies an alternating depletion and reload of energy storage. Anyhow, given the observation that obese individuals show much higher levels of uric acid as slim fit people ${ }^{57}$ the uricase mutation can be seen as a confirmation of Neel's thrifty gene hypothesis.

Regardless of the genetic debate, obesity establishes where industrialization arrives ${ }^{58}$. In this context, a clear trend can be observed in developing countries. If people leave their rural habitat and move to the cities, obesity and T2D are on the fast lane ${ }^{13,17,59}$. Modern inventions to make people's physical life more convenient are extremely successful (pedelecs, ready-to-eat-food, home automation etc.). When modern humans obtain the opportunity to save energy, they unconsciously select convenience, e.g. parking 
close to the entrance of a shopping center to avoid walking distances, favoring packaged food instead of spending hours preparing meals. Undoubtedly, this energy-saving behavior must have been shaped by evolution based on fluctuations in energy availability. The screw of time cannot be turned back, but the crucial question is: How can we remain metabolically healthy in a digital and saturated environment, which promotes sedentary behavior?

\section{The hunter and gatherer lifestyle}

Morning has broken: The foraging mode

Foraging is the vital need to search for food based on locomotion, which requires energy expenditure in the form of running, sneaking or sprinting to plunder big or small game or climbing and stooping in order to collect honey, berries, nuts, seeds and plants. Admittedly, human beings' ancestors always had to balance their investment of stored energy against the assumed outcome of a supposed foraging success ${ }^{60}$ to get physically active. The light-dark cycle forced organisms to develop a circadian rhythm to save energy and avoid predation by specialization to an active (light) and inactive (dark) period ${ }^{61}$. Independent from hunger, thirst or other motivational drives, the circadian rhythm ensures the initiation of the so-called cortisol awakening response $^{62}$. One major task of the glucocorticoid cortisol is binding to fat cells and glycogen storing tissues in the liver and skeletal muscles, when blood glucose concentration is $l_{0} w^{63}$. Cortisol levels increase autonomously in the morning before awakening to provide preferentially glucose for the brain and fatty acids for skeletal muscles to support foraging behavior, or physical activity in general. All behavior patterns in the context of physical activity are associated with energy demands of neurons and skeletal muscles, although energy intake was never predictable before the era of agriculture. As a result, to maintain homeostatic levels in terms of different environmental stimuli, humans inevitably became highly flexible in energy allocation ${ }^{64}$. In the morning, the circulating amount of glucose rises, a fact known as the dawn-phenomenon ${ }^{65}$. Simultaneously, the noninsulin-dependent glucose utilization is increased in skeletal muscles. Even muscles at rest demand more glucose in the morning than in the afternoon ${ }^{66}$. Animal studies show that if the metabolic rhythm is disturbed, e.g. due to night shifts or by exchanging the physical activity phase with the rest phase, the risk of glucose intolerance and obesity increases ${ }^{67}$. In contrast, fasting during the activity phase prevents metabolic disorders ${ }^{68}$. Those insights illustrate that autonomic endocrine functions prepare human organisms in the morning for physical activity independent of energy intake.

Across cultures and epochs, people always tend to consume three meals a day ${ }^{69}$. At daytime, leptin levels decrease and hunger signals emerge to increase sensitivity to brain reward systems, which boost the motivational drive of physical activity, facilitating foraging behavior ${ }^{70-72}$. Furthermore, lipolysis is upregulated due to activation of the hypothalamic-pituitary-adrenal (HPA) axis, the central nervous system and glucagon from pancreatic islets to induce $\beta$-oxidation of fatty acids, breakdown of glycogen and gluconeogenesis. In contrast, during night time, leptin levels increase, since appetite needs to be reduced in order not to disturb sleep by hunger signals. In addition, due to the fact that the activity of the HPA axis and the suprachiasmatic nucleus (SNS) are low, ketone body utilization provides energy for the brain, while growth hormone stimulated gluconeogenesis allocates glucose to the immune system ${ }^{73-76}$.

Responsible for controlling the circadian rhythm is the SNS. This core area of the hypothalamus can activate or silence various organs via the central nervous system. Both, the sympathetic and parasympathetic part of the central nervous system can subtly distinguish between intra-abdominal or subcutaneous fat by activating storage types depending on the vital necessity of the body $^{61,69}$. The fastest release of adiponectin, produced by adipocytes as a fundamental signal for the brain to modulate food intake $\mathrm{e}^{77}$, occurs at $10 \mathrm{a} . \mathrm{m}$. in the morning, synonymous with the greatest glucose tolerance ${ }^{78}$. Taken together, in the morning, human organisms are metabolically well prepared for physical activity, independent of energy intake. Accordingly, it seems contradicting that leading authorities throughout the developed world recommend high-glycemic foods for breakfast in order to provide energy for a sedentary daily routine, since cortisol has been generating energy at sunrise for more than 2.5 million years without energy intake ${ }^{62,79,80}$.

\section{Old danger signals: The fight-flight mode}

As all living organisms, humans maintain a dynamic homeostasis, which is constantly challenged by internal and external stressors ${ }^{81}$. The fight-flight response represents the archaic physiologic response to a threat from a danger signal ${ }^{82,83}$. In the history of mankind, humans always faced external threats, such as predators, storms, fire, hostile peers, and toxins in plants, meat or water, as well as internal immunological hazards, such as viruses, bacteria or fungi ${ }^{84}$. Dangerous situations were usually solved within minutes/hours/days (e.g. escape from predators) or at least weeks, because fighting acute infections or healing trauma could only last until all energy stores were empty, which means approximately 19 to 43 days for females and 28 to 41 days for males ${ }^{6,85}$.

In general, fighting and fleeing require augmented energetic demand to support locomotor behavior. Energy allocation is a prioritized issue in this context. If rapid muscle activation is important for survival, the SNS allocates energy to the brain, heart and large skeletal muscles ${ }^{83,86}$. Blood flow in muscles can increase from 1200 to $22,000 \mathrm{ml} / \mathrm{min}$. In contrast, blood flow to organs such as the kidneys or the viscera, which are energetically neglected in acute danger situations, decreases significantly ${ }^{87}$. The interplay of SNS-derived catecholamines and the secretion of cortisol, delivered by the HPA-axis, mobilizes glycogen and fatty acids from storage organs (muscles, liver, fat tissue) to provide fuel for the locomotor system. The reversion of an upregulated stress system to homeostasis is metabolically demanding. In case of an acute infection, each degree above normal body temperature costs a daily metabolic increase of $7-13 \%{ }^{88-90}$. Already moderate infections boost gluconeogenesis up to $150-200 \%$ and severe infections cost $15-30 \%$ of body weight due to a persistent elevated basal metabolic rate of $25-55 \%{ }^{91,92}$. Consequently, based on volatile environmental conditions, it 
becomes clear that humans' Paleolithic ancestors could not afford a chronically activated immune system, because hypermetabolism during an acute inflammation would become life-threatening if energy stores run empty. However, modern danger signals (e.g. psycho-emotional stress, high meal frequency, physical inactivity) chronically affect humans' immune system ${ }^{93-95}$. This persistent low-grade inflammation state is displayed by the mounting epidemic of non-communicable diseases in Western societies $^{96-98}$.

In acute danger situations, type 2 muscle fibers demand high amounts of glucose to initiate fighting or fleeing behavior ${ }^{18}$. In order to avoid a glucose conflict between the brain and contracting type 2 muscle fibers, evolution created alternative pathways to secure the energy demand of the brain. During high-intensity work, type 2 muscle fiber derived lactate is increasingly taken up and oxidized by type 1 muscle fibers and organs such as the heart and brain ${ }^{99}$ or - to a lesser extent of up to $20 \%$ clearance - recycled to glucose in the hepatic Cori cycle ${ }^{100,101}$. Similar to ketone bodies, brain lactate uptake is accomplished via monocarboxylate transporters, proportional to the arterial concentration of lactate, and able to reach a similar rate as glucose uptake, yielding up to one third of the carbon sources for oxidative phosphorylation ${ }^{102}$. Frequent exercise improves lactate removal $^{100}$ which subsequently may stimulate the production of brain-derived neurotrophic factor and improve cognitive performance ${ }^{103}$.

The flexibility to switch between metabolic pathways within seconds, prevented metabolic impairments of people's physical and cognitive performance, which was vital for survival in a hostile environment ${ }^{5,104}$. Danger and stress factors, affecting the Paleolithic ancestors, were acute within a relatively short timeframe and induced physical activity (escape) or sickness behavior and anorexia in case of an acute inflammation to overcome major wounds or severe infections as soon as possible ${ }^{105}$. Certainly, nowadays, modern humans suffer from chronic mental stress, which can last for days, weeks or even years with severe metabolic and psychiatric consequences ${ }^{84,106,107}$.

\section{Hungry eyes: The starvation mode}

Unlike today, human beings' Paleolithic ancestors could not predict meals. Human nutrition used to be subject to weekly, monthly as well as seasonal fluctuations ${ }^{108-110}$. Anyhow, in periods of fasting, humans should have been able to use stored energy, if necessary, for many hours or even days without any food supply. In other words, if pushing exogenous energy into the body used to be impossible due to food shortage in the past, energy allocation from energy stores to target tissue seems the only alternative to survive periods of food insecurity. For that reason, in late summer or at the end of a rainy season (the time of plenty), it became extremely important for our Paleolithic ancestors to take advantage of easily digestible carbohydrates, such as ripe fruits, to build up body fat, preparing for a scarcer food supply during winter or dry season (the time of caloric or carbohydrate restriction $)^{111}$. Homo sapiens adapted to these seasonal changes by developing several survival mechanisms. One example is given by the fructose transporter, which enables fruit-derived fructose to be allocated into cells independent of insulin ${ }^{112}$. In contrast to glucose (20\%), nearly $100 \%$ of all ingested fructose is immediately converted into fatty acids and then further esterified to storage triacylglycerols by the liver ${ }^{57,113-115}$. Adipose tissue, responsible for $60 \%$ of all triacylglycerol accumulation, can store large amounts of excess free fatty acids. The mechanism to convert fructose into fat was an important survival advantage for our ancestors, particularly if facing seasonal starvation periods. In the animal kingdom, hibernating species were not the only species that developed mechanisms to store energy, and protect themselves in times of food shortage. For example, northern elephant seals can fast for 60 days $^{116}$ and king penguins survive 5 months without energy intake ${ }^{27}$. Adipose tissue of modern humans contains approximately $13 \mathrm{~kg}$ fat or $500,000 \mathrm{~kJ}$, which would theoretically last for 2.4 months $^{34}$. As a result, survival was not only dependent on fitness, as argued by Charles Darwin ${ }^{117}$, but also on fatness, since overweight can guarantee weeks of survival without any food supply ${ }^{118}$. Alternatively, it can be imagined that early humans had to endure times not necessarily of reduced energy intake, but drastically reduced carbohydrate intake, if animal, but not plant foods were abundant. Physiologically, this situation is similar to fasting because it is mainly (exogenous) glucose that interferes with the adaptive response to fasting, while fat is a neutral macronutrient in this respect ${ }^{119}$. The nuclear peroxisome proliferator activating receptors that stimulate fat oxidation and ketogenesis are activated by free fatty acids, which can stem from both exogenous, preferably obtained from hunted animals, or endogenous fat, released during times of food scarcity ${ }^{120}$. It is interesting that across cultures, indigenous humans share a high preference for animal fat ${ }^{121,122}$, underscoring the importance of this macronutrient for human health and survival in times when only animal food was available.

Thus, intermittent fasting and longer-term caloric as well as carbohydrate restriction are parts of our genetic heritage. All three can lower glucose, insulin, triacylglycerol and lipid accumulation and, at the same time, increase insulin sensitivity, while increasing HDL-cholesterol ${ }^{123}$. Intermittent fasting itself was proven to significantly reduce low-grade-inflammation by degrading IL-6, TNF-alpha and CRP $109,124,125$. Studies with mice also demonstrated that time-restricted feeding without reducing caloric intake can prevent metabolic diseases, if fed a fattening $\operatorname{diet}^{68}$. Other evidence reveals that intermittent fasting and caloric restriction both enhance cardiovascular function and increase insulin sensitivity ${ }^{118,126}$. In humans, glucose homoeostasis in fasting periods is initially bypassed by liver glycogen ( 0.5 days) and proteolysis mainly from muscles (from day 1 to 3 ). From day 3 onwards, liver-derived ketone bodies are used as a main glucose substitute for the brain, muscles and immune cells ${ }^{74}$. Recapitulating, nature provides seasonal fluctuations of food availability, leading to alternating periods of fatness and leanness, whereas today, energy abundance determines modern life throughout the year.

Work first, then the reward: The rest mode

As mentioned before, food seeking behavior is an evolutionarybased motivational drive to forage, in order to maintain 
energy balance on homeostatic level. Foraging success in the form of food represents the primal reward for a physical effort, which activates parasympathetic circuits to promote digestion, recovery of energy stores and repair ${ }^{105,127-129}$. In order to avoid overnutrition, our metabolic homeostatic system involves several hormonal regulators of hunger and satiety, such as leptin, ghrelin, and insulin, which act on hypothalamic and brainstem circuits to inhibit further feeding. Dysfunction of this homeostatic system can result in a persistent state of positive energy balance, overeating and obesity. Palatable high caloric foods might be a major reason for this dysfunction in the Western world by exchanging the regulation of food intake from homeostatic to rewarding pathways ${ }^{106}$, since food intake displays much more than balancing energy status. Humans consume food also for its hedonic properties independent of energy status, revealing that the brain reward system plays an important role in feeding behavior $^{130}$. A pivotal component of reward and motivation circuitries is cerebral neurons, which originate in the ventral tegmental area. These cells send projections to the nucleus accumbens, a structure deep beneath the frontal cortex, by utilizing the essential neurotransmitter dopamine. Termed as the mesolimbic dopamine system, this brain region is responsible for the processing of aversion, motivation, pleasure and reward, and in consequence is linked to encoding rewarding stimuli, such as comfort food, sex, sports (runner's high), and addictive substances (caffeine, ethanol, nicotine, heroin, etc.) $)^{127,129,131}$. One hypothesis for abnormal hedonic behavior displayed by overconsumption of high-glycemic carbohydrates could be that modern processed foods lack in essential amino acids. In addition, processed foods contain less micronutrients compared to the Paleolithic food selection ${ }^{132,133}$. A poor nourishment status in both essential macro- and micronutrients might be at least co-responsible for reward deficiencies, which result in ongoing food seeking behavior rather than resting after enjoying the foraging success.

Affluence of energy-dense food is considered a major environmental risk factor for obesity ${ }^{134}$. Rats with extended access to palatable food rapidly gain weight and reward deficits ${ }^{127}$. Leptin resistance could be the functional link between reward deficiency and persistent ingestive behavior. Leptin receptors are expressed on dopamine neurons in the ventral tegmental $\operatorname{area}^{135}$. As proven in rodents, leptin infusions into the ventral tegmental area inhibit the activity of dopamine neurons and decrease food intake ${ }^{136}$. Further, knockdown of leptin receptors in the ventral tegmental area enhance food intake and preference for palatable food ${ }^{136}$. Administered from adipocytes leptin acts as an inhibitor of mesolimbic dopamine transmission in physiological conditions to interrupt food seeking behavior if storage organs are loaded. Obese individuals demonstrate increased activation of reward circuitries in response to palatable food compared with lean controls ${ }^{137,138}$. Apparently, hypersensitivity of reward circuitries predisposes to overnutrition and weight gain $^{139}$. However, during the further weight gain process, rewarding effects are blunted to reach hyposensitivity, which perpetuates overnutrition in order to overcome reward deficits $^{140,141}$. In conclusion, effort and reward are directly interconnected to silence dopamine-driven behavior. In Paleolithic times, reward substances were limited, whereas today modern humans are surrounded by a plethora of rewarding stimuli in a nearby environment, which can be addictive and finally inhibit physical activity.

\section{The sedentary lifestyle}

Modern habitat: A life in mental stress and physical rest

The current rise in metabolic diseases is descriptively explainable with a neglect of the important ancient metabolic programs. Our metabolic flexibility qualified us to be the most dominant of all living species on Earth. However, our energetic flexibility fell victim to major technical achievements of the last 150 years, a blink of an eye in an evolutionary point of view. For clarification, since 1887 food is stored in refrigerators, since 1900 muscle-derived energy expenditure is saved by the use of cars, and since 2001 people meet friends all around the world via the world-wide-web without investing a single calorie in locomotion. The inventions of the last three centuries increased physical inactivity. Moreover, the launch of high fructose corn syrup (HFCS)-production in the late 1980s has set up the crown on a sedentary lifestyle with abundance of nearby and easy to digest energy. Ever since, the obesity epidemic proceeds relentless ${ }^{4,114,142,143}$.

Many modern humans capitulate from the speed of innovation. Stress-related disorders are increasingly exorbitant ${ }^{144,145}$. Chronic psycho-emotional stress factors, such as liabilities, job loss or time pressure, face an archaic stress system (fight-flight-mode), made to overcome acute danger situations rather than long-term stress. Locomotion, the evolutionary designed solution to dismantle acute stress reactions, is no longer an option in a sedentary working ambiance. As a result, sedentary lifestyle in association with chronic psycho-emotional stress and a plethora of high-glycemic load foods, lead to a constant fueling of adipocytes, organs and other tissues ${ }^{146}$ (see Figure 2). Accordingly, we blame here three essential lifestyle factors for obesity and its related diseases:

1) Chronic high-glycemic food availability in the nearby environment

2) Loss of existential motivation for physical activity

3) Increase of psycho-emotional stress not ventilated by muscle activity

Good calories, bad calories: The burden of chronic energy availability

The modern lifestyle promotes continuous fueling of adipocytes (see Figure 2). In response to adipose hypertrophy, neutrophils, macrophages, natural killer cells and other immune cells infiltrate adipose tissue and in the further process develop an inflammatory environment, based on a phenotypic switch from anti-inflammatory M2- to pro-inflammatory M1-macrophages ${ }^{78,147}$. This condition induces a systemic low-grade inflammation, characterized by elevated levels of TNF-alpha and IL-6, which contributes to and amplifies insulin resistance ${ }^{19,21,23,148,149}$. As accumulation of adipose tissue approaches its limit, the body is compelled to use organs and other tissues for fat storage, 
such as skeletal muscles, pancreas, and liver, and as a second choice the heart, kidneys and bones, thereby boosting insulin resistance ${ }^{23,150-152}$. As a matter of fact, the liver is one of the organs affected first. A non-alcoholic fatty liver (NAFL) is present in nearly $25-50 \%$ of the general population in Western countries $^{152,153}$ and strongly related to T2D, hyperglycemia, hyperinsulinemia, low HDL-cholesterol and represents an independent risk factor for cardiovascular disease ${ }^{154}$. It is striking that changes in lifestyle patterns opposing those of a sedentary lifestyle such as physical activity, exercise, periods of calorie restriction or cold water immersion seem to exert holistic beneficial effects on body composition, NAFL and low-grade inflammation ${ }^{155,156-160}$.

Glucose is the primary nutrient for neurons and red blood cells, but rather rare in our primal habitat. Therefore, honey has always been a privileged food for hunter-gatherers, and accounts for a substantial proportion of kilocalories in some primal living societies, since honey is the most energy dense food in nature. In the Hadza diet (a hunter and gatherer tribe in Tanzania), honey contributes roughly $15 \%$ of their total energy intake ${ }^{161}$. At least in warm areas, honey might have been a regular part of humans' hunter-gatherer past, since current indigenous people take not inconsiderable risks to gain access. All of humans closest relatives, like chimpanzees, bonobos, gorillas and orangutans, consume honey. Honey is the sugar source par excellence, as its dry matter contains $95 \%$ of carbohydrates, averaged $40 \%$ fructose and $30 \%$ glucose $^{162}$. For this reason, honey is the ideal fuel to supply the central nervous system with glucose and simultaneously refill fat stores with fructose for both animals and humans living in the wild to stand seasonal fluctuations of energy availability. Today, fructose is ubiquitous as a low-cost sweetener. In the late 1980s, the US food industry began incorporating HFCS into soft drinks and industrial foods, greatly promoting the persistent caloric surplus in present day societies ${ }^{163}$. It has now become clear that regular consumption of processed and high-glycemic load foods, especially sugar-sweetened soft drinks $s^{55,57,164}$, supported by a growing lack of exercise, change human body composition towards an accumulation of visceral fat mass and sarcopenia ${ }^{165,166}$. As a result, the reduction of sugarsweetened foods might be one of the major key factors to overcome the obesity epidemic.

\section{Sit and wait: Metabolic consequences of sedentary behavior}

The capability to store fat inside muscles could have been an evolutionary advantage to preserve the existential motivation to hunt and gather food in times of shortage. Observational studies of recent hunter-gatherer societies, such as the Hadza in Tanzania, forager groups of the Andaman Islands or the San people in the Kalahari Desert, reveal that men usually walk long distances for hunting animals, while women search for collectable food and fresh water in the nearby environment ${ }^{60,167-169}$. Most physical activities of the mentioned aboriginal tribes are movements at low intensities, where skeletal muscles use fatty acids as the primary energy source. Oxidative type 1 muscle fibers are characterized by a higher fat content than glycolytic type 2 fibers. They contain more mitochondria, which utilize stored intramuscular fat as a rapidly available energy source.
Therefore, oxidative slow-twitch muscle fibers are perfectly designed to overcome long distances in order to forage or see new biospheres. Interestingly, high intramuscular fat is associated with both the development of insulin resistance and the effects of endurance training, known as the training paradox in sports physiology ${ }^{170}$. Although fat accumulation in muscles of obese people is a consequence of a spillover of nutrient excess in sedentary terms, it has been suggested that the supercompensation of intramuscular fat after fasting periods or exhaustive workouts could have been beneficial in human evolution to permit physical activity in times of food shortage ${ }^{171}$. De facto, if prolonged exercise (hunting big game or discovering new hunting grounds) was vital for survival in the past, high intramuscular fat stores secure $\beta$-oxidation in active muscle cells ${ }^{18,104}$. In this situation, glucose can be spared for the central nervous system (at daytime), glucose-depending cells (e.g. red blood and kidney cells) and the immune system (at night) - an excellent metabolic division of work on the scarcity of glucose to guarantee a constant glucose influx to glucose-depending cells $^{34,172,173}$

Nowadays, the biggest metabolic challenge for obese, (pre-)diabetic, metabolically inflexible healthy individuals, but also athletes on high carbohydrate diets, is to maintain blood sugar levels in an affluent environment. In conditions of high locomotor speed, chronic mental activation or insulin resistance, there is an increasing demand of glucose either by type 2 muscle fibers (in high-intensity conditions) or the brain (in chronic mental activation or under insulin resistance). In dangerous situations, when muscle activity beyond $70 \%$ VO2max is needed for survival (or nowadays in competitive sports), the utilization rate of muscle and liver glycogen can come to its limits ${ }^{33,104,172}$. Consequently, the euglycemic state is compromised and metabolically inflexible athletes typically show symptoms of neuroglycopenia, which are commonly answered or prevented by the intake of carbohydrate-rich foods. This situation would be different in "keto-adapted" athletes, who are able to sustain fat oxidation at high intensities and display high levels of ketone bodies during exercise, which can be used by the brain. These capabilities have been impressively documented by Volek et al. ${ }^{173}$, showing that in keto-adapted endurance athletes peak fat oxidation is shifted towards higher intensities $(70 \pm 6 \%$ of $\left.\mathrm{VO}_{2} \max \right)$ and displays absolute values more than twice as large $(1.2 \pm 0.2 \mathrm{~g} / \mathrm{min})$ as those of endurance athletes on a high carbohydrate diet. Apart from athletes, owing to the digital sedentary lifestyle that affects all aspects of life, modern humans frequently walk less than $1 \mathrm{~km}$ per day, their physical activity level has fallen below 1.7, and their $\mathrm{VO}_{2}$ max fitness markers

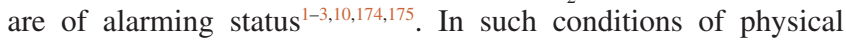
inactivity, the need for carbohydrates as a fuel is at a minimum level. By contrast, most authorities in the Western world recommend at least $50 \%$ of the daily caloric intake as carbohydrates for a sedentary lifestyle ${ }^{176-179}$. Although the brain accounts for about $2 / 3$ of the total daily glucose turnover ${ }^{180}$, the brain is not capable of accumulating large amounts of glucose. Since high blood sugar levels are pro-inflammatory ${ }^{9,181,182}$, excess glucose, if not utilized by the brain or muscles, has to be metabolized in the liver as fat, continuously fueling adipocytes (see Figure 2) 
Even humans with a constitutional high percentage of fasttwitch fibers, which are competent to burn high amounts of glucose within a short timeframe, have given up this opportunity to clear glucose from the blood in a digital world. These subjects rapidly store fat given a Western diet in physical rest ${ }^{104,183-186}$. In Paleolithic times, this adaptation could have been a survival advantage in specific environmental conditions, but, nowadays, it seriously impairs metabolic health.

\section{In a hurry: Modern stressors and visceral fat storage}

Like all biological systems, physical and mental stress is mutually dependent on the dynamic homeostasis. For example, it is well established that an overload of exercise activates humans' immune system and provides a higher vulnerability to infectious diseases $^{187-190}$. In modern societies, physical workload is increasingly detached from intellectual workplaces. In the light of working conditions at present, a significant trend can be observed that once humans enter sedentary professions, they become overweight ${ }^{191}$. Nowadays, in an affluent environment under the influence of multiple new stressors, people's primal systems can come to their limits. Social hierarchy is a perfect example to display individual stress load. Sapolsky ${ }^{192,193}$ found that in baboons social subordinance and social isolation is associated with manifestations of hypercortisolism. In modern working organizations, the mean cortisol level is higher in individuals with low socioeconomic status because of high job demands. The same holds true for low job control in general ${ }^{194}$. Many overstressed people experience long-term stress since they are not capable of changing their self-chosen or enforced environment ${ }^{195}$. From a biological perspective, intense muscle activity is the natural response to stressful or dangerous stimuli. At the present day, exercise has lost its primal role due to the fact that modern humans living in a digital environment do not secure their subsistence by physical workload anymore. Exercise no longer serves as either foraging behavior or escaping from dangerous conditions and fighting predators. If modern humans are mentally hyperactive (e.g. chess playing on world class level), skeletal muscles become insulin resistant for a short time, to redirect glucose towards the central nervous system $^{196}$. In this case, humans' brains rapidly demand glucose replenishment when stressors continue ${ }^{37,89,197}$. In the long run, a temporary functional insulin resistance, which secures survival of neurons in acute danger or infectious situations, passes over into a persistent insulin resistant state. This condition was recently viewed as protective to avoid abundant intracellular substrate accumulation, especially in liver and muscle cells ${ }^{198}$. However, as a consequence of prolonged insulin resistance, insulin receptors are blunted and transmembrane signaling is attenuated $^{199-201}$.

\section{Conclusions}

A return to Stone Age conditions is neither possible nor desirable. Plants are highly cultured, movement has lost its existential necessity to forage, and stress influences act no longer as acute danger signals but are subtly persistent. Paleolithic times were certainly no paradise. Modern achievements such as food preservation, mechanization, antibiotics, high-tech medicine and the virtual elimination of infant mortality have significantly increased life expectancy in the Western biosphere ${ }^{202}$. Even contemporary hunter-gatherers do not reach the age of modern humans, predominantly due to much higher rates of infant mortality and serious, unhandled infections ${ }^{203}$. Nevertheless, the era in which modern humans suffer from chronic diseases is extending $^{204}$ and metabolic disorders occur much earlier ${ }^{16,21,205,206}$. Periodic fat gain is considered physiologic, whereas persistent overweight contradicts humans' evolutionary designed metabolic flexibility and promotes a chronic low-grade inflammation, which can be considered as the hotbed for WD. Apparently, since evolution is a slow-acting process, modern humans are not yet well adapted to a sedentary lifestyle. Approximately $99.5 \%$ of our existence, we lived as hunter-gatherers ${ }^{1,2}$, being metabolically prepared for any kind of environmental condition. According to the present article, today's sedentary lifestyle limits our primal metabolic flexibility to a stress and rest mode (see Figure 1 and Figure 2), while the starvation and foraging mode are consistently neglected if not consciously integrated in daily life. Regular activation of these modes, however, appears necessary to maintain metabolic flexibility in a modern habitat, characterized by energy abundance, prolonged psychosocial stress and physical inactivity. While certain drugs or "calorie restriction mimetics" such as metformin or resveratrol appear as a convenient way of activating signaling networks associated with the starvation and foraging mode, they are not able to fully mimic the complex adaptions and molecular signaling taking place with actual lifestyle interventions. For the latter we argue that no specific diet, exercise or anti-stress program must be followed if behavior is adjusted based on human being's evolutionary heritage. Examples include, but are not limited to, periodic fasting or calorie restriction (e.g., once a year as traditionally practiced within the world religions), occasional meal skipping, ketogenic diets (e.g., during the winter months) and a combination of endurance and strength training several times per week.

\section{Competing interests}

No competing interests were declared.

\section{Grant information}

The author(s) declared that no grants were involved in supporting this work.

\section{Acknowledgments}

We would like to thank the four reviewers and Dr. Dieter Möller for constructive comments on a previous version of the paper. 
1. O'Keefe JH, Vogel R, Lavie CJ, et al.: Achieving hunter-gatherer fitness in the 21(st) century: back to the future. Am J Med. 2010; 123(12): 1082-6. PubMed Abstract | Publisher Full Text

2. O'Keefe $\mathrm{JH}$, Vogel R, Lavie CJ, et al.: Organic fitness: physical activity consistent with our hunter-gatherer heritage. Phys Sportsmed. 2010; 38(4): 11-8. PubMed Abstract | Publisher Full Text

3. O'Keefe JH, Vogel R, Lavie CJ, et al:: Exercise like a hunter-gatherer: a prescription for organic physical fitness. Prog Cardiovasc Dis. 2011; 53(6): 471-9. PubMed Abstract | Publisher Full Text

4. Speakman JR: Evolutionary perspectives on the obesity epidemic: adaptive, maladaptive, and neutral viewpoints. Annu Rev Nutr. 2013; 33: 289-317. PubMed Abstract | Publisher Full Text

5. Galgani JE, Moro C, Ravussin E: Metabolic flexibility and insulin resistance. $A m$ J Physiol Endocrinol Metab. 2008; 295(5): E1009-17. PubMed Abstract | Publisher Full Text | Free Full Text

6. Straub RH: Evolutionary medicine and chronic inflammatory state--known and new concepts in pathophysiology. J Mol Med (Berl). 2012; 90(5): 523-34. PubMed Abstract | Publisher Full Text | Free Full Text

7. Speakman JR, Mitchell SE: Caloric restriction. Mol Aspects Med. 2011; 32(3): 159-221.

PubMed Abstract | Publisher Full Text

8. van Praag $\mathrm{H}$, Fleshner M, Schwartz MW, et al:: Exercise, energy intake, glucose homeostasis, and the brain. J Neurosci. 2014; 34(46): 15139-49. PubMed Abstract | Publisher Full Text | Free Full Text

9. Chakravarthy MV, Booth FW: Eating, exercise, and "thrifty" genotypes: connecting the dots toward an evolutionary understanding of modern chronic diseases. J Appl Physiol (1985). 2004; 96(1): 3-10. PubMed Abstract | Publisher Full Text

10. Booth FW, Roberts CK, Laye MJ: Lack of exercise is a major cause of chronic diseases. Compr Physiol. 2012; 2(2): 1143-211. PubMed Abstract | Publisher Full Text | Free Full Text

11. Leonard WR: The global diversity of eating patterns: human nutritional health in comparative perspective. Physiol Behav. 2014; 134: 5-14. PubMed Abstract | Publisher Full Text

12. Chopra M, Galbraith S, Darnton-Hill I: A global response to a global problem: the epidemic of overnutrition. Bull World Health Organ. 2002; 80(12): 952-8. PubMed Abstract | Free Full Text

13. Foliaki S, Pearce N: Prevalence and causes of diabetes in Pacific people. Pac Health Dialog. 2003; 10(2): 90-98. PubMed Abstract

14. Schulz LO, Bennett PH, Ravussin E, et al:: Effects of traditional and western environments on prevalence of type 2 diabetes in Pima Indians in Mexico and the U.S. Diabetes Care. 2006; 29(8): 1866-71.

PubMed Abstract | Publisher Full Text

15. Farag YM, Gaballa MR: Diabesity: an overview of a rising epidemic. Nephrol Dial Transplant. 2011; 26(1): 28-35.

PubMed Abstract | Publisher Full Text

16. Hamilton MT, Hamilton DG, Zderic TW: Sedentary behavior as a mediator of type 2 diabetes. Med Sport Sci. 2014; 60: 11-26.

PubMed Abstract | Publisher Full Text | Free Full Text

17. Chan JC, Cho NH, Tajima N, et al.: Diabetes in the Western Pacific Region--past, present and future. Diabetes Res Clin Pract. 2014; 103(2): 244-55. PubMed Abstract | Publisher Full Text

18. Kelley DE, Mandarino LJ: Fuel selection in human skeletal muscle in insulin resistance: a reexamination. Diabetes. 2000; 49(5): 677-683. PubMed Abstract | Publisher Full Text

19. Dandona $\mathrm{P}, \mathrm{Aljada} A$, Bandyopadhyay A: Inflammation: the link between insulin resistance, obesity and diabetes. Trends Immunol. 2004; 25(1): 4-7. PubMed Abstract | Publisher Full Text

20. Egger G, Dixon J: Non-nutrient causes of low-grade, systemic inflammation: support for a 'canary in the mineshaft' view of obesity in chronic disease. Obes Rev. 2011; 12(5): 339-45.

PubMed Abstract | Publisher Full Text

21. Rodríguez-Hernández H, Simental-Mendía LE, Rodríguez-Ramírez G, et al.: Obesity and inflammation: epidemiology, risk factors, and markers of inflammation. Int J Endocrinol. 2013; 2013: 678159. PubMed Abstract | Publisher Full Text | Free Full Text

22. Ruiz-Núñez B, Pruimboom L, Dijck-Brouwer DA, et al:: Lifestyle and nutritional imbalances associated with Western diseases: causes and consequences of chronic systemic low-grade inflammation in an evolutionary context. $J$ Nutr Biochem. 2013; 24(7): 1183-201.

PubMed Abstract | Publisher Full Text

23. Montecucco F, Steffens S, Mach F: Insulin resistance: a proinflammatory state mediated by lipid-induced signaling dysfunction and involved in atherosclerotic plaque instability. Mediators Inflamm. 2008; 2008: 767623. PubMed Abstract | Publisher Full Text | Free Full Text

24. Bosma-den Boer MM, van Wetten ML, Pruimboom L: Chronic inflammatory diseases are stimulated by current lifestyle: how diet, stress levels and medication prevent our body from recovering. Nutr Metab (Lond). 2012; 9(1): 32. PubMed Abstract | Publisher Full Text | Free Full Text
25. Garland T Jr, Schutz H, Chappell MA, et al:: The biological control of voluntary exercise, spontaneous physical activity and daily energy expenditure in relation to obesity: human and rodent perspectives. J Exp Biol. 2011; 214(Pt 2): 206-29. PubMed Abstract | Publisher Full Text | Free Full Text

26. Södersten $\mathrm{P}$, Nergårdh $\mathrm{R}$, Bergh $\mathrm{C}$, et al:: Behavioral neuroendocrinology and treatment of anorexia nervosa. Front Neuroendocrinol. 2008; 29(4): 445-62. PubMed Abstract | Publisher Full Text

27. Longo VD, Mattson MP: Fasting: molecular mechanisms and clinical applications. Cell Metab. 2014; 19(2): 181-92. PubMed Abstract | Publisher Full Text | Free Full Text

28. Pruimboom L, Raison CL, Muskiet FA: Physical Activity Protects the Human Brain against Metabolic Stress Induced by a Postprandial and Chronic Inflammation. Behav Neurol. 2015; 2015: 569869. PubMed Abstract | Publisher Full Text | Free Full Text

29. Aiello LC, Wheeler P: The expensive-tissue hypothesis: The brain and the digestive system in human and primate evolution. Curr Anthropol. 1995; 36(2): 199-221. Publisher Full Text

30. Navarrete A, van Schaik CP, Isler K: Energetics and the evolution of human brain size. Nature. 2011; 480(7375): 91-3. PubMed Abstract | Publisher Full Text

31. Cunnane SC, Crawford MA: Survival of the fattest: fat babies were the key to evolution of the large human brain. Comp Biochem Physiol A Mol Integr Physiol. 2003; 136(1): 17-26.

PubMed Abstract | Publisher Full Text

32. Kuipers RS, Luxwolda MF, Dijck-Brouwer DA, et al.: Estimated macronutrient and fatty acid intakes from an East African Paleolithic diet. Br J Nutr. 2010; 104(11): 1666-87.

PubMed Abstract | Publisher Full Text

33. Peters $\mathrm{A}$, Schweiger $\mathrm{U}$, Pellerin $\mathrm{L}$, et al.: The selfish brain: competition for energy resources. Neurosci Biobehav Rev. 2004; 28(2): 143-80. PubMed Abstract | Publisher Full Text

34. Straub RH: Insulin resistance, selfish brain, and selfish immune system: an evolutionarily positively selected program used in chronic inflammatory diseases. Arthritis Res Ther. 2014; 16(Suppl 2): S4 PubMed Abstract | Publisher Full Text | Free Full Text

35. Hitze B, Hubold C, van Dyken R, et al.: How the selfish brain organizes its supply and demand. Front Neuroenergetics. 2010; 2: 7. PubMed Abstract | Publisher Full Text | Free Full Text

36. Peters A, Kubera B, Hubold C, et al:: The selfish brain: stress and eating behavior. Front Neurosci. 2011; 5: 74

PubMed Abstract | Publisher Full Text | Free Full Text

37. Kubera B, Hubold C, Zug S, et al:: The brain's supply and demand in obesity. Front Neuroenergetics. 2012; 4: 4. PubMed Abstract | Publisher Full Text | Free Full Text

38. Peters A, Pellerin L, Dallman MF, et al.: Causes of obesity: looking beyond the hypothalamus. Prog Neurobiol. 2007; 81(2): 61-88. PubMed Abstract | Publisher Full Text

39. Peters A, Hitze B, Langemann D, et al.: Brain size, body size and longevity. Int J Obes (Lond). 2010; 34(8): 1349-52. PubMed Abstract | Publisher Full Text

40. Courchesne-Loyer A, Croteau E, Castellano CA, et al:: Inverse relationship between brain glucose and ketone metabolism in adults during short-term moderate dietary ketosis: A dual tracer quantitative positron emission tomography study. J Cereb Blood Flow Metab. 2017. 37(7): 2485-2493. PubMed Abstract | Publisher Full Text | Free Full Text

41. Valdebenito R, Ruminot I, Garrido-Gerter $P$, et al:: Targeting of astrocytic glucose metabolism by beta-hydroxybutyrate. J Cereb Blood Flow Metab. 2016; 36(10): 1813-1822.

PubMed Abstract | Publisher Full Text | Free Full Text

42. Takahashi S, lizumi T, Mashima K, et al:: Roles and regulation of ketogenesis in cultured astroglia and neurons under hypoxia and hypoglycemia. ASN Neuro. 2014; 6(5): pii: 1759091414550997.

PubMed Abstract | Publisher Full Text | Free Full Text

43. Peters A, Hubold C, Lehnert H: Gehirn und Metabolisches Syndrom. Der Diabetologe. 2008; 4(3): 189-195. Publisher Full Text

44. Peters A, Langemann D: Build-ups in the supply chain of the brain: on the neuroenergetic cause of obesity and type 2 diabetes mellitus. Front Neuroenergetics. 2009; 1: 2.

PubMed Abstract | Publisher Full Text | Free Full Text

45. Eaton SB, Strassman BI, Nesse RM, et al.: Evolutionary health promotion. Prev Med. 2002; 34(2): 109-18. PubMed Abstract | Publisher Full Text

46. Prentice AM: Early influences on human energy regulation: thrifty genotypes and thrifty phenotypes. Physiol Behav. 2005; 86(5): 640-5. PubMed Abstract | Publisher Full Text

47. Prentice AM, Hennig BJ, Fulford AJ: Evolutionary origins of the obesity epidemic: natural selection of thrifty genes or genetic drift following predation release? Int J Obes (Lond). 2008; 32(11): 1607-10. PubMed Abstract | Publisher Full Text 
48. Aguiree F, Brown A, Cho NH, et al:: IDF diabetes atlas. 2013 Reference Source

49. Stannard SR, Johnson NA: Insulin resistance and elevated triglyceride in muscle: more important for survival than "thrifty" genes? J Physiol. 2004 554(Pt 3): 595-607.

PubMed Abstract | Publisher Full Text | Free Full Text

50. Levitan RD, Wendland B: Novel "thrifty" models of increased eating behaviour. Curr Psychiatry Rep. 2013; 15(11): 408. PubMed Abstract | Publisher Full Text

51. Speakman JR: Thrifty genes for obesity, an attractive but flawed idea, and an alternative perspective: the 'drifty gene' hypothesis. Int J Obes (Lond). 2008; 32(11): 1611-7.

PubMed Abstract | Publisher Full Text

52. Berbesque JC, Marlowe FW, Shaw $P$, et al:: Hunter-gatherers have less famine than agriculturalists. Biol Lett. 2014; 10(1): 20130853.

PubMed Abstract | Publisher Full Text | Free Full Text

53. Johnson RJ, Andrews P: Fructose, uricase, and the back-to-Africa hypothesis. Evol Anthropol. 2010; 19(6): 250-257.

Publisher Full Text

54. Kratzer JT, Lanaspa MA, Murphy MN, et al:: Evolutionary history and metabolic insights of ancient mammalian uricases. Proc Natl Acad Sci U S A. 2014 111(10): 3763-8

PubMed Abstract | Publisher Full Text | Free Full Text

55. Malik VS, Popkin BM, Bray GA, et al:: Sugar-sweetened beverages and risk of metabolic syndrome and type 2 diabetes: a meta-analysis. Diabetes Care. 2010; 33(11): 2477-83

PubMed Abstract | Publisher Full Text | Free Full Text

56. Popkin BM, Hawkes C: Sweetening of the global diet, particularly beverages: patterns, trends, and policy responses. Lancet Diabetes Endocrinol. 2016; 4(2): 174-186.

PubMed Abstract | Publisher Full Text | Free Full Text

57. Johnson RJ, Nakagawa T, Sanchez-Lozada LG, et al:: Sugar, uric acid, and the etiology of diabetes and obesity. Diabetes. 2013; 62(10): 3307-15. PubMed Abstract | Publisher Full Text | Free Full Text

58. Hu FB: Resolved: There is sufficient scientific evidence that decreasing sugarsweetened beverage consumption will reduce the prevalence of obesity and obesity-related diseases. Obes Rev. 2013; 14(8): 606-19. PubMed Abstract | Publisher Full Text | Free Full Text

59. Brownell KD, Yach D: Lessons from a small country about the global obesity crisis. Global Health. 2006; 2: 11

PubMed Abstract | Publisher Full Text | Free Full Text

60. Pontzer H, Raichlen DA, Wood BM, et al.: Energy expenditure and activity among Hadza hunter-gatherers. Am J Hum Biol. 2015; 27(5): 628-37. PubMed Abstract | Publisher Full Text

61. Kreier F, Kalsbeek A, Ruiter M, et al.: Central nervous determination of food storage--a daily switch from conservation to expenditure: implications for the metabolic syndrome. Eur J Pharmacol. 2003; 480(1-3): 51-65. PubMed Abstract | Publisher Full Text

62. Fries E, Dettenborn L, Kirschbaum C: The cortisol awakening response (CAR): facts and future directions. Int J Psychophysiol. 2009; 72(1): 67-73. PubMed Abstract | Publisher Full Text

63. Woods CP, Hazlehurst JM, Tomlinson JW: Glucocorticoids and non-alcoholic fatty liver disease. J Steroid Biochem Mol Biol. 2015; 154: 94-103. PubMed Abstract | Publisher Full Text

64. Bailey SM, Udoh US, Young ME: Circadian regulation of metabolism $J$ Endocrinol. 2014; 222(2): R75-96. PubMed Abstract | Publisher Full Text | Free Full Text

65. Bolli GB, De Feo P, De Cosmo S, et al:: Demonstration of a dawn phenomenon in normal human volunteers. Diabetes. 1984; 33(12): 1150-1153. PubMed Abstract | Publisher Full Text

66. Arble DM, Sandoval DA: CNS control of glucose metabolism: response to environmental challenges. Front Neurosci. 2013; 7: 20 PubMed Abstract | Publisher Full Text | Free Full Text

67. Salgado-Delgado R, Tapia Osorio A, Saderi N, et al:: Disruption of circadian rhythms: a crucial factor in the etiology of depression. Depress Res Treat. 2011; 2011: 839743

PubMed Abstract | Publisher Full Text | Free Full Text

68. Hatori M, Vollmers C, Zarrinpar A, et al:: Time-restricted feeding without reducing caloric intake prevents metabolic diseases in mice fed a high-fat diet. Cell Metab. 2012; 15(6): 848-60. PubMed Abstract | Publisher Full Text | Free Full Text

69. Garaulet M, Madrid JA: Chronobiological aspects of nutrition, metabolic syndrome and obesity. Adv Drug Deliv Rev. 2010; 62(9-10): 967-78. PubMed Abstract | Publisher Full Text

70. Carr KD: Feeding, drug abuse, and the sensitization of reward by metabolic need. Neurochem Res. 1996; 21(11): 1455-1467. PubMed Abstract | Publisher Full Text

71. Langendonk JG, Pijl H, Toornvliet AC, et al:: Circadian rhythm of plasma leptin levels in upper and lower body obese women: influence of body fat distribution and weight loss. J Clin Endocrinol Metab. 1998; 83(5): 1706-1712. PubMed Abstract | Publisher Full Text
72. Chen Z, Kenny PJ: Running on Empty: Leptin Signaling in VTA Regulates Reward from Physical Activity. Cell Metab. 2015; 22(4): 540-1.

PubMed Abstract | Publisher Full Text

73. Gimble JM, Floyd ZE: Fat circadian biology. J Appl Physiol (1985). 2009; 107(5): 1629-37.

PubMed Abstract | Publisher Full Text | Free Full Text

74. Straub $\mathrm{RH}$, Cutolo $\mathrm{M}$, Buttgereit $\mathrm{F}$, et al:: Energy regulation and neuroendocrineimmune control in chronic inflammatory diseases. J Intern Med. 2010; 267(6): 543-60.

PubMed Abstract | Publisher Full Text

75. Shostak $\mathrm{A}$, Husse $\mathrm{J}$, Oster $\mathrm{H}$ : Circadian regulation of adipose function. Adipocyte. 2013; 2(4): 201-6.

PubMed Abstract | Publisher Full Text | Free Full Text

76. Luchetti $\mathrm{F}$, Canonico B, Bartolini D, et al.: Melatonin regulates mesenchymal stem cell differentiation: a review. J Pineal Res. 2014; 56(4): 382-97. PubMed Abstract | Publisher Full Text

77. Guerre-Millo M: Adiponectin: an update. Diabetes Metab. 2008; 34(1): 12-8. PubMed Abstract | Publisher Full Text

78. Wensveen FM, Valentić S, Šestan M, et al:: Interactions between adipose tissue and the immune system in health and malnutrition. Semin Immunol. 2015; 27(5): 322-33.

PubMed Abstract | Publisher Full Text

79. Kirschbaum C, Hellhammer DH: Salivary cortisol. Encyclopedia of Stress. 2000; 3

80. Zilberter T, Zilberter EY: Breakfast: to skip or not to skip? Front Public Health 2014; 2 : 59

PubMed Abstract | Publisher Full Text | Free Full Text

81. Chrousos GP: Stress and disorders of the stress system. Nat Rev Endocrinol. 2009; 5(7): 374-81.

PubMed Abstract | Publisher Full Text

82. Bracha HS: Freeze, flight, fight, fright, faint: adaptationist perspectives on the acute stress response spectrum. CNS Spectr. 2004; 9(9): 679-85. PubMed Abstract | Publisher Full Text

83. McEwen BS: Physiology and neurobiology of stress and adaptation: central role of the brain. Physiol Rev. 2007; 87(3): 873-904.

PubMed Abstract | Publisher Full Text

84. Arnoldini M, Mostowy R, Bonhoeffer S, et al.: Evolution of stress response in the face of unreliable environmental signals. PLOS Comput Biol. 2012; 8(8): e1002627.

PubMed Abstract | Publisher Full Text | Free Full Text

85. Korte SM, Koolhaas JM, Wingfield JC, et al:: The Darwinian concept of stress: benefits of allostasis and costs of allostatic load and the trade-offs in health and disease. Neurosci Biobehav Rev. 2005; 29(1): 3-38. PubMed Abstract | Publisher Full Text

86. Peters A, McEwen BS: Stress habituation, body shape and cardiovascula mortality. Neurosci Biobehav Rev. 2015; 56: 139-50.

PubMed Abstract | Publisher Full Text

87. Ball D: Metabolic and endocrine response to exercise: sympathoadrenal integration with skeletal muscle. J Endocrinol. 2015; 224(2): R79-95. PubMed Abstract | Publisher Full Text

88. Segerstrom SC: Resources, stress, and immunity: an ecological perspective on human psychoneuroimmunology. Ann Behav Med. 2010; 40(1): 114-25. PubMed Abstract | Publisher Full Text

89. Demas GE: The energetics of immunity: a neuroendocrine link between energy balance and immune function. Horm Behav. 2004; 45(3): 173-80. PubMed Abstract | Publisher Full Text

90. Segerstrom SC: Stress, Energy, and Immunity: An Ecological View. Curr Dir Psychol Sci. 2007; 16(6): 326-330.

PubMed Abstract | Publisher Full Text | Free Full Text

91. Lochmiller RL, Deerenberg C: Trade-offs in evolutionary immunology: Just what is the cost of immunity? Oikos. 2000; 88(1): 87-98. Publisher Full Text

92. McDade TW, Georgiev AV, Kuzawa CW: Trade-offs between acquired and innate immune defenses in humans. Evol Med Public Health. 2016; 2016(1): 1-16. PubMed Abstract | Publisher Full Text | Free Full Text

93. Bianchi ME: DAMPs, pamps and alarmins: all we need to know about danger. J Leukoc Biol. 2007; 81(1): 1-5.

PubMed Abstract | Publisher Full Text

94. Castellheim A, Brekke OL, Espevik T, et al.: Innate immune responses to danger signals in systemic inflammatory response syndrome and sepsis. Scand $J$ Immunol. 2009; 69(6): 479-91.

PubMed Abstract | Publisher Full Text

95. Klop B, Proctor SD, Mamo JC, et al.: Understanding postprandial inflammation and its relationship to lifestyle behaviour and metabolic diseases. Int $J$ Vasc Med. 2012; 2012: 947417.

PubMed Abstract | Publisher Full Text | Free Full Text

96. Wärnberg J, Nova E, Romeo J, et al:: Lifestyle-related determinants of inflammation in adolescence. Br J Nutr. 2007; 98 Suppl 1: S116-20. PubMed Abstract | Publisher Full Text

97. de Punder K, Pruimboom L: Stress induces endotoxemia and low-grade inflammation by increasing barrier permeability. Front Immunol. 2015; 6: 223. PubMed Abstract | Publisher Full Text | Free Full Text 
98. Miller $\mathrm{AH}$, Raison $\mathrm{CL}$ : The role of inflammation in depression: from evolutionary imperative to modern treatment target. Nat Rev Immunol. 2016; 16(1): 22-34. PubMed Abstract | Publisher Full Text | Free Full Text

99. Dienel GA: Brain lactate metabolism: the discoveries and the controversies. J Cereb Blood Flow Metab. 2012; 32(7): 1107-38. PubMed Abstract | Publisher Full Text | Free Full Text

100. Donovan CM, Brooks GA: Endurance training affects lactate clearance, not lactate production. Am J Physiol. 1983; 244(1): E83-92. PubMed Abstract | Publisher Full Text

101. Brooks GA: The lactate shuttle during exercise and recovery. Med Sci Sports Exerc. 1986; 18(3); 360-8. PubMed Abstract | Publisher Full Text

102. Overgaard M, Rasmussen $\mathrm{P}$, Bohm AM, et al:: Hypoxia and exercise provoke both lactate release and lactate oxidation by the human brain. FASEB J. 2012; 26(7): 3012-20. PubMed Abstract | Publisher Full Text

103. Proia P, Di Liegro CM, Schiera G, et al.: Lactate as a Metabolite and a Regulator in the Central Nervous System. Int J Mol Sci. 2016; 17(9): pii: E1450. PubMed Abstract | Publisher Full Text | Free Full Text

104. Storlien L, Oakes ND, Kelley DE: Metabolic flexibility. Proc Nutr Soc. 2004; 63(2): $363-8$.

PubMed Abstract | Publisher Full Text

105. Straub RH, Schradin C: Chronic inflammatory systemic diseases: An evolutionary trade-off between acutely beneficial but chronically harmful programs. Evol Med Public Health. 2016; 2016(1): 37-51. PubMed Abstract | Publisher Full Text | Free Full Text

106. Adam TC, Epel ES: Stress, eating and the reward system. Physiol Behav. 2007; 91(4): 449-58. PubMed Abstract | Publisher Full Tex

107. Dhabhar FS: Effects of stress on immune function: the good, the bad, and the beautiful. Immunol Res. 2014; 58(2-3): 193-210. PubMed Abstract | Publisher Full Text

108. Mattson MP, Duan W, Guo Z: Meal size and frequency affect neuronal plasticity and vulnerability to disease: Cellular and molecular mechanisms. J Neurochem. 2003; 84(3): 417-431. PubMed Abstract | Publisher Full Text

109. Mattson MP: Energy intake, meal frequency, and health: a neurobiological perspective. Annu Rev Nutr. 2005; 25: 237-60. PubMed Abstract | Publisher Full Text

110. Rigby N: Eating and obesity--the new world disorder. Nutrients. 2013; 5(10): 4206-10. PubMed Abstract | Publisher Full Text | Free Full Text

111. Naviaux RK: Metabolic features of the cell danger response. Mitochondrio. 2014; 16: 7-17. PubMed Abstract | Publisher Full Tex

112. Wilder-Smith $\mathrm{CH}$, Li X, Ho SS, et al:: Fructose transporters GLUT5 and GLUT2 expression in adult patients with fructose intolerance. United European Gastroenterol J. 2014; 2(1): 14-21. PubMed Abstract | Publisher Full Text | Free Full Text

113. Lustig RH: Fructose: metabolic, hedonic, and societal parallels with ethanol. J Am Diet Assoc. 2010; 110(9): 1307-21. PubMed Abstract | Publisher Full Text

114. Lustig RH: Fructose: it's "alcohol without the buzz". Adv Nutr. 2013; 4(2): 226-35. PubMed Abstract | Publisher Full Text | Free Full Text

115. Ameer F, Scandiuzzi L, Hasnain S, et al.: De novo lipogenesis in health and disease. Metabolism. 2014; 63(7): 895-902. PubMed Abstract | Publisher Full Text

116. Hays GC, Broderick AC, Glen F, et al:: Change in body mass associated with long-term fasting in a marine reptile: The case of green turtles (chelonia mydas) at ascension island. Can J Zool. 2002; 80(7): 1299-1302. Publisher Full Text

117. Darwin C: On the origin of species. Mineola, New York: Dover Publications, Inc. 2006 Reference Source

118. Mattson MP, Wan R: Beneficial effects of intermittent fasting and caloric restriction on the cardiovascular and cerebrovascular systems. J Nutr Biochem. 2005; 16(3): 129-37. PubMed Abstract | Publisher Full Text

119. Klein S, Wolfe RR: Carbohydrate restriction regulates the adaptive response to fasting. Am J Physiol. 1992; 262(5 Pt 1): E631-6. PubMed Abstract | Publisher Full Tex

120. Kurtak KA: Dietary and nutritional manipulation of the nuclear transcription factors peroxisome proliferator-activated receptor and sterol regulatory element-binding proteins as a tool for reversing the primary diseases of premature death and delaying aging. Rejuvenation Res. 2014; 17(2): 140-4. PubMed Abstract | Publisher Full Text

121. Speth JD: The paleoanthropology and archaeology of big-game hunting: Protein, fat, or politics? New York: Springer, 2010 Publisher Full Text

122. Ben-Dor M: Use of animal fat as a symbol of health in traditional societies suggests humans may be well adapted to its consumption. J Evol Health. 2015; 1(1): 10 Publisher Full Text
123. Freese J, Pardi DJ, Ruiz-Núñez B, et al.: Back to the future. Metabolic effects of a 4-day outdoor trip under simulated paleolithic conditions - new insights from the eifel study. J Evol Health. 2016; 1(1): 16.

Publisher Full Text

124. Azevedo FR, Ikeoka D, Caramelli B: Effects of intermittent fasting on metabolism in men. Rev Assoc Med Bras (1992). 2013; 59(2): 167-73. PubMed Abstract | Publisher Full Text

125. Michalsen A, Li C: Fasting therapy for treating and preventing disease - current state of evidence. Forsch Komplementmed. 2013; 20(6): 444-53. PubMed Abstract | Publisher Full Text

126. Weiss EP, Fontana $\mathrm{L}$ : Caloric restriction: powerful protection for the aging heart and vasculature. Am J Physiol Heart Circ Physiol 2011; 301(4): H1205-19. PubMed Abstract | Publisher Full Text | Free Full Text

127. Kenny PJ: Reward mechanisms in obesity: new insights and future directions. Neuron. 2011; 69(4): 664-79.

PubMed Abstract | Publisher Full Text | Free Full Text

128. Kolling N, Behrens TE, Mars RB, et al:: Neural mechanisms of foraging. Science. 2012; 336(6077): 95-8. PubMed Abstract | Publisher Full Text | Free Full Text

129. Jauch-Chara K, Oltmanns KM: Obesity--a neuropsychological disease? Systematic review and neuropsychological model. Prog Neurobiol. 2014; 114: 84-101. PubMed Abstract | Publisher Full Text

130. Lutter $\mathrm{M}$, Nestler $\mathrm{EJ}$ : Homeostatic and hedonic signals interact in the regulation of food intake. J Nutr. 2009; 139(3): 629-32. PubMed Abstract | Publisher Full Text | Free Full Text

131. Esch T, Stefano GB: Endogenous reward mechanisms and their importance in stress reduction, exercise and the brain. Arch Med Sci. 2010; 6(3): 447-55. PubMed Abstract | Publisher Full Text | Free Full Text

132. Eaton SB, Konner MJ, Cordain L: Diet-dependent acid load, Paleolithic [corrected] nutrition, and evolutionary health promotion. Am J Clin Nutr. 2010; 91(2): 295-7. PubMed Abstract | Publisher Full Text

133. Carrera-Bastos $P$, Fontes $O$, Lindeberg $C$ : The western diet and lifestyle and diseases of civilization. Research Reports in Clinical Cardiology. 2011; 2: 15-35. Publisher Full Text

134. Volkow ND, Wise RA: How can drug addiction help us understand obesity? Nat Neurosci. 2005; 8(5): 555-60.

PubMed Abstract | Publisher Full Text

135. Khanh DV, Choi $\mathrm{YH}$, Moh SH, et al.: Leptin and insulin signaling in dopaminergic neurons: relationship between energy balance and reward system. Front Psychol. 2014; 5: 846. PubMed Abstract | Publisher Full Text | Free Full Text

136. Hommel JD, Trinko $\mathrm{R}$, Sears $\mathrm{RM}$, et al.: Leptin receptor signaling in midbrain dopamine neurons regulates feeding. Neuron. 2006; 51(6): 801-10. PubMed Abstract | Publisher Full Text

137. Gautier $A$, Bonnet $F$, Dubois $S$, et al: Associations between visceral adipose tissue, inflammation and sex steroid concentrations in men. Clin Endocrinol (Oxf). 2013; 78(3): 373-8.

PubMed Abstract | Publisher Full Text

138. Rothemund $Y$, Preuschhof $C$, Bohner G, et al:: Differential activation of the dorsa striatum by high-calorie visual food stimuli in obese individuals. Neuroimage. 2007; 37(2): 410-21.

PubMed Abstract | Publisher Full Text

139. Stice $\mathrm{E}$, Yokum $\mathrm{S}$, Blum $\mathrm{K}$, et al.: Weight gain is associated with reduced striatal response to palatable food. J Neurosci. 2010; 30(39): 13105-9. PubMed Abstract | Publisher Full Text | Free Full Text

140. Stice E, Spoor S, Bohon C, et al.: Relation of reward from food intake and anticipated food intake to obesity: a functional magnetic resonance imaging study. J Abnorm Psychol. 2008; 117(4): 924-35. PubMed Abstract | Publisher Full Text | Free Full Text

141. Wang GJ, Volkow ND, Fowler JS: The role of dopamine in motivation for food in humans: implications for obesity. Expert Opin Ther Targets. 2002; 6(5): 601-9. PubMed Abstract | Publisher Full Text

142. Collino M: High dietary fructose intake: Sweet or bitter life? World J Diabetes. 2011; 2(6): 77-81. PubMed Abstract | Publisher Full Text | Free Full Text

143. Walker RW, Dumke KA, Goran MI: Fructose content in popular beverages made with and without high-fructose corn syrup. Nutrition. 2014; 30(7-8): 928-35. PubMed Abstract | Publisher Full Text

144. Badura B, Ducki A, Schröder H, et al:: Fehlzeiten-Report 2015. 2014. Publisher Full Text

145. BKK Gesundheitsreport: Gesundheit in Bewegung. Schwerpunkt Muskel-und Skeletterkrankungen. 2013; (Stand, 20, 2014.) Reference Source

146. Mazzali G, Fantin F, Zoico E, et al:: Heart Fat Infiltration In Subjects With and Without Coronary Artery Disease. J Clin Endocrinol Metab. 2015; 100(9): 3364-71. PubMed Abstract | Publisher Full Text

147. Harford KA, Reynolds CM, McGillicuddy FC, et al.: Fats, inflammation and insulin resistance: insights to the role of macrophage and T-cell accumulation in adipose tissue. Proc Nutr Soc. 2011; 70(4): 408-17. PubMed Abstract | Publisher Full Text 
148. Buechler C, Krautbauer S, Eisinger K: Adipose tissue fibrosis. World J Diabetes. 2015; 6(4): 548-53

PubMed Abstract | Publisher Full Text | Free Full Text

149. Grant RW, Dixit VD: Adipose tissue as an immunological organ. Obesity (Silver Spring). 2015; 23(3): 512-8.

PubMed Abstract | Publisher Full Text | Free Full Text

150. Ströhle A, Worm N: [Healthy obesity? Why the adiposity paradox is only seemingly paradox]. Med Monatsschr Pharm. 2014; 37(2): 54-64; quiz 65-6. PubMed Abstract

151. Cordain L, Eades MR, Eades MD: Hyperinsulinemic diseases of civilization: more than just Syndrome X. Comp Biochem Physiol A Mol Integr Physiol. 2003; 136(1): 95-112. PubMed Abstract | Publisher Full Text

152. Bellentani $\mathrm{S}$, Scaglioni $\mathrm{F}$, Marino $\mathrm{M}$, et al.: Epidemiology of non-alcoholic fatty liver disease. Dig Dis. 2010; 28(1): 155-61. PubMed Abstract | Publisher Full Text

153. Klement RJ, Albers T, Kämmerer U, et al.: Proceedings of the 1st Annual Symposium of the German Society for Paleo Nutrition held in 2013. J Evol Health. 2013; 1(1): 5 . Publisher Full Text

154. Sattar N, Forrest E, Preiss D: Non-alcoholic fatty liver disease. BMJ. 2014; 349(sep19 15): g4596 PubMed Abstract | Publisher Full Text | Free Full Text

155. Than NN, Newsome PN: A concise review of non-alcoholic fatty liver disease. Atherosclerosis. 2015; 239(1): 192-202. PubMed Abstract | Publisher Full Text

156. Ott B, Skurk T, Hastreiter L, et al:: Effect of caloric restriction on gut permeability, inflammation markers, and fecal microbiota in obese women. $S c$ Rep. 2017; 7(1): 11955 PubMed Abstract | Publisher Full Text | Free Full Text

157. Meydani SN, Das SK, Pieper CF, et al.: Long-term moderate calorie restriction inhibits inflammation without impairing cell-mediated immunity: a randomized controlled trial in non-obese humans. Aging (Albany NY). 2016; 8(7): 1416-31. PubMed Abstract | Publisher Full Text | Free Full Text

158. Chen J, Guo Y, Gui Y, et al.: Physical exercise, gut, gut microbiota, and atherosclerotic cardiovascular diseases. Lipids Health Dis. 2018; 17(1): 17. PubMed Abstract | Publisher Full Text

159. Silverman MN, Deuster PA: Biological mechanisms underlying the role of physical fitness in health and resilience. Interface Focus. 2014; 4(5): 20140040. PubMed Abstract | Publisher Full Text | Free Full Text

160. Wash K, Burnet S, Steele J: Brace yourselves, winter is coming: a pilot study of the effects of brief, infrequent cold water immersion upon body composition in young adult males. 2017; 2(2): 4. Publisher Full Text

161. Marlowe FW, Berbesque JC, Wood B, et al:: Honey, Hadza, hunter-gatherers, and human evolution. J Hum Evol. 2014; 71: 119-28. PubMed Abstract | Publisher Full Text

162. Bogdanov S, Jurendic $\mathrm{T}$, Sieber R, et al.: Honey for nutrition and health: a review. J Am Coll Nutr. 2008; 27(6): 677-689. PubMed Abstract | Publisher Full Text

163. White JS: Straight talk about high-fructose corn syrup: what it is and what it ain’t. Am J Clin Nutr. 2008; 88(6): 1716S-1721S. PubMed Abstract | Publisher Full Tex

164. Choi JW, Ford ES, Gao X, et al:: Sugar-sweetened soft drinks, diet soft drinks, and serum uric acid level: the Third National Health and Nutrition Examination Survey. Arthritis Rheum. 2008; 59(1): 109-16. PubMed Abstract | Publisher Full Tex

165. Wells JC: The evolution of human adiposity and obesity: where did it all go wrong? Dis Model Mech. 2012; 5(5): 595-607. PubMed Abstract | Publisher Full Text | Free Full Text

166. Bellisari A: Evolutionary origins of obesity. Obes Rev. 2008; 9(2): 165-80. PubMed Abstract | Publisher Full Text

167. Bogin B: !Kung nutritional status and the original "affluent society"--a new analysis. Anthropol Anz. 2011; 68(4): 349-366. PubMed Abstract | Publisher Full Text

168. Sahani R: Foraging to settled life: a comparative study of anthropometry and nutrition of Onges of Little Andaman Island. Homo. 2013; 64(5): 391-7. PubMed Abstract | Publisher Full Text

169. Hawkes K, O'Connell JF, Jones NG: More lessons from the Hadza about men's work. Hum Nat. 2014; 25(4): 596-619. PubMed Abstract | Publisher Full Tex

170. Goodpaster $\mathrm{BH}, \mathrm{He} \mathrm{J}$, Watkins $\mathrm{S}$, et al: Skeletal muscle lipid content and insulin resistance: evidence for a paradox in endurance-trained athletes. $J$ Clin Endocrinol Metab. 2001; 86(12): 5755-5761. PubMed Abstract | Publisher Full Text

171. Schrauwen-Hinderling VB, Hesselink MK, Schrauwen P, et al:: Intramyocellula lipid content in human skeletal muscle. Obesity (Silver Spring). 2006; 14(3): 357-367.

PubMed Abstract | Publisher Full Text

172. Richter EA, Hargreaves M: Exercise, GLUT4, and skeletal muscle glucose uptake. Physiol Rev. 2013; 93(3): 993-1017. PubMed Abstract | Publisher Full Text
173. Volek JS, Noakes T, Phinney SD: Rethinking fat as a fuel for endurance exercise. Eur J Sport Sci. 2015; 15(1): 13-20.

PubMed Abstract | Publisher Full Text

174. Cordain L, Gotshall RW, Eaton SB, et al:: Physical activity, energy expenditure and fitness: an evolutionary perspective. Int J Sports Med. 1998; 19(5): 328-335. PubMed Abstract | Publisher Full Text

175. Pedersen BK, Fischer CP: Beneficial health effects of exercise--the role of IL-6 as a myokine. Trends Pharmacol Sci. 2007; 28(4): 152-6. PubMed Abstract | Publisher Full Text

176. http://www.health.gov/dietaryguidelines/2015/guidelines

177. http://www.dge.de/ernaehrungspraxis/vollwertige-ernaehrung/10-regeln-derdge/

178. http://www.sge-ssn.ch/ich-und-du/essen-und-trinken/ausgewogen/schweizerlebensmittelpyramide/

179. http://www.oege.at/index.php/bildung-information/empfehlungen

180. Peters A: The selfish brain: Competition for energy resources. Am J Hum Biol. 2011; 23(1): 29-34.

PubMed Abstract | Publisher Full Text

181. Dandona P, Chaudhuri A, Ghanim H, et al.: Proinflammatory effects of glucose and anti-inflammatory effect of insulin: relevance to cardiovascular disease. Am J Cardiol. 2007; 99(4A): 15B-26B. PubMed Abstract | Publisher Full Text

182. Dandona $\mathrm{P}$, Chaudhuri $\mathrm{A}$, Ghanim $\mathrm{H}$, et al:: Insulin as an anti-inflammatory and antiatherogenic modulator. J Am Coll Cardiol. 2009; 53(5 Suppl): S14-20. PubMed Abstract | Publisher Full Text

183. Cahova M, Vavrinkova $H$, Kazdova L: Glucose-fatty acid interaction in skeletal muscle and adipose tissue in insulin resistance. Physiol Res. 2007; 56(1): 1-15. PubMed Abstract

184. Izumiya $\mathrm{Y}$, Hopkins $\mathrm{T}$, Morris $\mathrm{C}$, et al.: Fast/glycolytic muscle fiber growth reduces fat mass and improves metabolic parameters in obese mice. Cell Metabolism. 2008; 7(2): 159-72.

PubMed Abstract | Publisher Full Text | Free Full Text

185. Nielsen J, Christensen DL: Glucose intolerance in the west african diaspora: A skeletal muscle fibre type distribution hypothesis. Acta Physiol (Oxf). 2011; 202(4): 605-16.

PubMed Abstract | Publisher Full Tex

186. Egan B, Zierath JR: Exercise metabolism and the molecular regulation of skeletal muscle adaptation. Cell Metabolism. 2013; 17(2): 162-84. PubMed Abstract | Publisher Full Text

187. Gleeson M: Immune function in sport and exercise. J Appl Physiol (1985). 2007; 103(2): 693-9.

PubMed Abstract | Publisher Full Text

188. Gleeson M, Pyne DB: Respiratory inflammation and infections in highperformance athletes. Immunol Cell Biol. 2016; 94(2): 124-31. PubMed Abstract | Publisher Full Text

189. Couto $M$, Silva $D$, Delgado $L$, et al.: Exercise and airway injury in athletes. Acta Med Port. 2013; 26(1): 56-60. PubMed Abstract

190. Walsh NP, Oliver SJ: Exercise, immune function and respiratory infection: An update on the influence of training and environmental stress. Immunol Cell Biol. 2016; 94(2): 132-9.

PubMed Abstract | Publisher Full Tex

191. Hauner $\mathrm{H}$, Bramlage $\mathrm{P}$, Lösch $\mathrm{C}$, et al.: Overweight, obesity and high waist circumference: regional differences in prevalence in primary medical care. Dtsch Arztebl Int. 2008; 105(48): 827-33. PubMed Abstract | Publisher Full Text | Free Full Text

192. Sapolsky RM, Alberts SC, Altmann J: Hypercortisolism associated with social subordinance or social isolation among wild baboons. Arch Gen Psychiatry. 1997; 54(12): 1137-43.

PubMed Abstract | Publisher Full Tex

193. Sapolsky RM: The influence of social hierarchy on primate health. Science. 2005; 308(5722): 648-52. PubMed Abstract | Publisher Full Tex

194. Kunz-Ebrecht SR, Kirschbaum C, Steptoe A: Work stress, socioeconomic status and neuroendocrine activation over the working day. Soc Sci Med. 2004; 58(8): 1523-30.

PubMed Abstract | Publisher Full Text

195. Heraclides AM, Chandola T, Witte DR, et al:: Work stress, obesity and the risk of type 2 diabetes: gender-specific bidirectional effect in the whitehall II study. Obesity (Silver Spring). 2012; 20(2): 428-33. PubMed Abstract | Publisher Full Text

196. Troubat N, Fargeas-Gluck MA, Tulppo M, et al: The stress of chess players as a model to study the effects of psychological stimuli on physiological responses: An example of substrate oxidation and heart rate variability in man. Eur J Appl Physiol. 2009; 105(3): 343-9. PubMed Abstract | Publisher Full Text

197. Peters A, McEwen BS: Introduction for the allostatic load special issue. Physiol Behav. 2012; 106(1): 1-4. PubMed Abstract | Publisher Full Tex

198. Connor T, Martin SD, Howlett, KF, et al.: Metabolic remodelling in obesity and type 2 diabetes: Pathological or protective mechanisms in response to 
nutrient excess? Clin Exp Pharmacol Physiol. 2015; 42(1): 109-15. PubMed Abstract | Publisher Full Text

199. Bailey CJ: Treating insulin resistance: future prospects. Diab Vasc Dis Res. 2007; 4(1): 20-31.

PubMed Abstract | Publisher Full Text

200. Eaton SB, Cordain L, Sparling PB: Evolution, body composition, insulin receptor competition, and insulin resistance. Prev Med. 2009; 49(4): 283-5. PubMed Abstract | Publisher Full Text

201. Samuel VT, Shulman Gl: The pathogenesis of insulin resistance: Integrating signaling pathways and substrate flux. J Clin Invest. 2016; 126(1): 12-22. PubMed Abstract | Publisher Full Text | Free Full Text

202. Lopez AD, Mathers CD, Ezzati M, et al.: Global and regional burden of disease and risk factors, 2001: Systematic analysis of population health data. Lancet.
2006; 367(9524): 1747-57.

PubMed Abstract | Publisher Full Text

203. Hill K, Hurtado AM, Walker RS: High adult mortality among Hiwi huntergatherers: implications for human evolution. J Hum Evol. 2007; 52(4): 443-54. PubMed Abstract | Publisher Full Text

204. Bijl R, Boelhouwer J, Pommer E, et al:: The social state of the netherlands 2009 The Sociale State of the Netherlands.pdf. n.d. Reference Source

205. Tappy L, Lê KA: Metabolic effects of fructose and the worldwide increase in obesity. Physiol Rev. 2010; 90(1): 23-46. PubMed Abstract | Publisher Full Text

206. Bedogni G, Nobili V, Tiribelli C: Epidemiology of fatty liver: An update. World J Gastroenterol. 2014; 20(27): 9050-4. PubMed Abstract | Free Full Text 


\section{Open Peer Review}

\section{Current Peer Review Status:}

\section{Version 1}

Reviewer Report 06 December 2017

https://doi.org/10.5256/f1000research.13782.r28692

(C) 2017 Kumagai S. This is an open access peer review report distributed under the terms of the Creative Commons Attribution License, which permits unrestricted use, distribution, and reproduction in any medium, provided the original work is properly cited.

\section{Shuzo Kumagai \\ Faculty of Arts and Science, Kyushu University, Kasuga City, Japan}

This article published by Jens Freese et al. discussed the potential explanations of metabolic epidemic from the viewpoint of the metabolic flexibility sharped by evolutionary through millions of years, and a combination of present-day continuous food abundance, sedentary lifestyle, and psycho-emotional stress. In their manuscript, Jens Freese et al suggested metabolic programs relying on fatty acid and ketone body oxidation are most of the time shut off due to modern lifestyle and have to be reintegrated in order to overcome the obesity epidemic.

The storyline of 'Survival the most flexible' section could be more clear if the description could be more concise and focusing on how evolution sharped the metabolic flexibility. For example, the content of 'It's all about survival: Why evolution shaped metabolic flexibility' seems discussed the interplay of metabolic programs in brain and other organs (e.g., skeletal muscle and adipocytes) which could be combined into the first section. The sections regarding uricase mutation could also be more straightforward by describing the importance of this mutation (e.g., more efficient metabolism of fructose and fat stores) in the way of evolution.

In the section of 'Sedentary lifestyle', the authors described a modern lifestyle which is opposite to the 'The hunter and gatherer lifestyle'. Accordingly, this section could also benefit from a more concise storyline by comparisons such as sedentary behavior vs foraging mode. Besides molecular-level evidence, there are also quite a lot of epidemiological evidence has highlighted the importance of environmental, and behavioral (dietary and sedentary behaviors) factors in the progress of metabolic health outcomes. Incorporation of these evidences will provide more insight into how to re-cultivate of suppressed evolutionarily metabolic programs and make the proposed model more convincing and readily understood for the researchers in the field as well as the general readers.

\section{Is the topic of the opinion article discussed accurately in the context of the current literature?}

Yes

Are all factual statements correct and adequately supported by citations? 
Partly

Are arguments sufficiently supported by evidence from the published literature? Partly

Are the conclusions drawn balanced and justified on the basis of the presented arguments? Partly

Competing Interests: No competing interests were disclosed.

Reviewer Expertise: Health and Exercise Epidemiology, Exercise Physiology

I confirm that I have read this submission and believe that I have an appropriate level of expertise to confirm that it is of an acceptable scientific standard, however I have significant reservations, as outlined above.

Author Response 29 Jan 2018

Jens Freese, Deutsche Sporthochschule Köln, Germany

We would like to thank all reviewers for their constructive comments and positive feedback to our article. We have addressed their comments as described below, and think that they greatly helped to improve our article further.

The storyline of 'Survival the most flexible' section could be more clear if the description could be more concise and focusing on how evolution sharped the metabolic flexibility. For example, the content of 'It's all about survival: Why evolution shaped metabolic flexibility' seems discussed the interplay of metabolic programs in brain and other organs (e.g., skeletal muscle and adipocytes) which could be combined into the first section. The sections regarding uricase mutation could also be more straightforward by describing the importance of this mutation (e.g., more efficient metabolism of fructose and fat stores) in the way of evolution.

A: We have moved parts from the "Survival of the most flexible" section into the "It's all about survival: Why evolution shaped metabolic flexibility"' section, and also joined both sections together to better connect the lines of reasoning provided in them. We have also re-structured and shortened the section on the uricase mutation in order to make our argumentation more comprehensible.

In the section of 'Sedentary lifestyle', the authors described a modern lifestyle which is opposite to the 'The hunter and gatherer lifestyle'. Accordingly, this section could also benefit from a more concise storyline by comparisons such as sedentary behavior vs foraging mode. Besides molecular-level evidence, there are also quite a lot of epidemiological evidence has highlighted the importance of environmental, and behavioral (dietary and sedentary behaviors) factors in the progress of metabolic health outcomes. Incorporation of these evidences will provide more insight into how to re-cultivate of suppressed evolutionarily metabolic programs and make the proposed model more convincing and readily understood for the researchers in the field as well as the general 
readers.

A: We have removed some redundant text from the first subsection "Modern habitat: A life in mental stress and physical rest" in order to make the storyline and transition to the following subsections more concise. We have also added a total of five new references that provide additional confirmation of our hypothesis that reverting the sedentary lifestyle induces holistic beneficial metabolic effects.

Competing Interests: No competing interest.

Reviewer Report 27 November 2017

https://doi.org/10.5256/f1000research.13782.r28024

(c) 2017 Coy J. This is an open access peer review report distributed under the terms of the Creative Commons Attribution License, which permits unrestricted use, distribution, and reproduction in any medium, provided the original work is properly cited.

\section{Johannes Coy}

Tavartis GmbH, Hainburg, Germany

The article 'The sedentary (r)evolution: Have we lost our metabolic flexibility?' by Freese and coworkers is an important contribution to solve the huge worldwide problem caused by a dramatic increase of diseases linked to nutrition and life style.

The authors describe that during the course of evolution, up until the agricultural revolution, environmental fluctuations forced the human species to develop a flexible metabolism in order to adapt its energy needs to various climate, seasonal and vegetation conditions. During the longest time of Homo sapiens' existence, humans' daily survival was shaped by food insecurity (feast and famine), adaptation to a widespread range of different food sources (biodiversity), abundant daily exercise frequently under fasting conditions (foraging behavior), as well as unpredictable food supply (intermitted fasting), depending on the daily foraging success.

The authors underline that the metabolic flexibility safeguarded human survival independent of changes in food availability and food composition. Furthermore the article shows the important and complex interplay and regulation of different metabolic pathways and a very important metabolic switch to the use of ketone bodies and fat oxidation.

In the course of evolution, environmental stress forced the human species to develop an extraordinary flexible metabolism with multiple programs to guarantee energy equilibrium. Lipolysis, proteolysis, gluconeogenesis, ketone bodies and muscle-derived lactate as alternative energy substrates for cerebral neurons, provide examples by which natural selection tailored humans to buffer fluctuations in energy supply. Hormons as important key regulators of the 
metabolism as well as the role of the brain are being described in a very good and understandable way. In addition as a result of persistent psycho-emotional stressors the reaction of the brain concomitant with the changes in metabolism is shown. Furthermore the important impact of a lack of exercise is depicted.

Due to this clear description of the metabolic flexibility and the absence of the use of this metabolic flexibility in modern humans following a Western life type, the authors hypothesize that the modern energetic inflexibility, typically displayed by symptoms of neuroglycopenia, can be reversed by re-activation of certain suppressed metabolic programs, which became obsolete in an affluent environment, particularly the ability to easily switch to ketone body and fat oxidation.

The approach to re-activate metabolic programs represents an important and a not-well known approach to prevent and treat diseases related to metabolism and life style. Therefore this article is of utmost importance for scientists and clinicians in this field, but also enables individual humans to use the knowledge presented in this article to re-activate the metabolic programs by intermitting fasting, changes in food composition and/or exercises e.g. to activate the program to use ketone bodies and fat oxidation.

There are a few terms which should be considered / could be changed to make the statements more clear.

\section{Abstract:}

"In this article, we argue that the metabolic epidemic is largely based on a deficit in metabolic flexibility."

The term 'metabolic epidemic' should be rephrased e.g.

In this article, we argue that the strong increase of diseases related with an metabolic impact is largely based on a deficit in metabolic flexibility.

The same should be done for the sentence in the introduction:

"In this article, we argue that the metabolic epidemic in the developed world is based on a deficit in metabolic flexibility,..."

\section{Page 7}

"Adipose tissue, responsible for $60 \%$ of all triacylglycerol accumulation, can store large amounts of excess FFA."

The Abbreviation FFA is not being explained

\section{Page 9}

"On a related note, changes in lifestyle patterns have been more successful in the context of a NAFL than pharmacological treatments, whereas exercise in isolation has not been proven to be effective." 
...the statement 'whereas exercise in isolation has not been proven to be effective' should be explained. The meaning of 'exercise in isolation' is not clear.

Is the topic of the opinion article discussed accurately in the context of the current literature?

Yes

Are all factual statements correct and adequately supported by citations? Yes

Are arguments sufficiently supported by evidence from the published literature? Yes

Are the conclusions drawn balanced and justified on the basis of the presented arguments? Yes

Competing Interests: No competing interests were disclosed.

I confirm that I have read this submission and believe that I have an appropriate level of expertise to confirm that it is of an acceptable scientific standard.

Author Response 29 Jan 2018

Jens Freese, Deutsche Sporthochschule Köln, Germany

We would like to thank all reviewers for their constructive comments and positive feedback to our article. We have addressed their comments as described below, and think that they greatly helped to improve our article further.

"In this article, we argue that the metabolic epidemic is largely based on a deficit in metabolic flexibility."

The term 'metabolic epidemic' should be rephrased e.g.

In this article, we argue that the strong increase of diseases related with an metabolic impact is largely based on a deficit in metabolic flexibility.

The same should be done for the sentence in the introduction:

"In this article, we argue that the metabolic epidemic in the developed world is based on a deficit in metabolic flexibility,..."

A: Done. We rephrased the term as "diseases related to metabolic abnormalities"

\section{Page 7}

"Adipose tissue, responsible for $60 \%$ of all triacylglycerol accumulation, can store large amounts of excess FFA." 
The Abbreviation FFA is not being explained

\title{
A: We apologize and have replaced the abbreviation with "free fatty acids"
}

\section{Page 9}

"On a related note, changes in lifestyle patterns have been more successful in the context of a NAFL than pharmacological treatments, whereas exercise in isolation has not been proven to be effective."

...the statement 'whereas exercise in isolation has not been proven to be effective' should be explained. The meaning of 'exercise in isolation' is not clear.

\section{A: The meaning should be „Exercise on its own without concurrent changes in diet". However, the whole sentence was removed and replaced by a related sentence.}

\author{
Competing Interests: No competing interest.
}

Reviewer Report 27 November 2017

https://doi.org/10.5256/f1000research.13782.r27936

(C) 2017 Yadav $\mathrm{U}$ et al. This is an open access peer review report distributed under the terms of the Creative Commons Attribution License, which permits unrestricted use, distribution, and reproduction in any medium, provided the original work is properly cited.

\section{Umesh Yadav}

School of Life Sciences, Central University of Gujarat, Gandhinagar, India

Johnna F. Varghese

School of Life Sciences, Central University of Gujarat, Gandhinagar, India

The manuscript entitled "The sedentary (r)evolution: Have we lost our metabolic flexibility?" by Freese J. et al., has discussed an important issue regarding the molecular and evolutionary reasons behind increased incidence of modern life style diseases in human beings. The authors have cited interesting studies to corroborate their points and delivered a convincing molecular and biochemical outlook for Western diseases (WD). The article makes an interesting read for the commoners as well as the scientific community.

As far as the deficit in the metabolic flexibility in the modern times, as opposed to prehistoric times, is concerned the arguments given sound rational and justifiable, especially the switch between the fatty acid oxidation verses glucose oxidation in the hunter and gatherers of early times, which the authors argue has been lost in the modern times due to 1., availability of high glycemic food; 2., lack of extensive physical activities; 3., chronic psychological stress. 
The authors have discussed the relationship between the organs and shift in the metabolic flux during the two different lifestyles, hunter and gatherers, and sedentary. The metabolic linkages with circadian rhythm during hunter and gatherers life style, and how it has got disturbed now, are well explained.

However, there are certain points authors may like to connect to make it more explicable. Take an example where the transition of life style was not abrupt, the hunter and gatherers when became agricultural societies and started dwelling in the stable communities with no uncertainty in most of the life activities, and feast and famine were not as frequent. Did the biochemical changes in the metabolism undergo some adaptation to the relatively and progressively 'sedentary life style'? The agricultural societies have now transformed into industrialized societies with modern amenities and energy-rich foods within arm's reach.

Evolution indeed is a progressive natural mechanism. Is it possible that the 'thrifty genes' that became advantageous during hunting and gathering era of human existence, has become a sort of burden and will be eventually eliminated from the gene pool? Probably a better adapted gene set, say 'lean genes' to these emerging trends would help humans survive the endemic 'modern life style'. Are there any indication of such evolutionary tendencies in humans today? Can the modern tools such as CRISPER-Cas be utilized in near future to modify the so called 'thrifty genes' and to rewire the metabolic flexibility? This is especially important when the evolution depends more on artificial selection than natural!

The life, and the metabolism that drives life, are flexible and would therefore evolve an alternate mechanism to handle the pressure of modern life style on human health and survival. What biochemical alternatives or shunts could be suggested to overcome the so called metabolic inflexibility. Authors may have suggested or postulated more credible ways to thwart the metabolic inflexibility than merely propounding 'retrain all prescribed modes periodically', where the term 'periodically' is clearly vague!

At places the authors have mentioned about the satiety signalling, where they state that leptin resistance is a common scenario in the sedentary life style. Is there evidence that the satiety signaling involving leptin and ghrelin have evolved in favour with the progressing inactive lifestyle?

The authors have well explained the brain reward system in feeding behaviour. Modern habits and lifestyle is inclined towards abnormal hedonic behaviour where there is an excessive intake of processed food with high glycemic index and low nutritive value, dissatisfaction to the brain drives such a behaviour leading to obesity. Could authors suggest ways or quote studies where balancing the nutritive value of the food has been attempted such that they regulate the hormonal homeostasis that controls the excessive eating behaviour in individuals?

\author{
Is the topic of the opinion article discussed accurately in the context of the current \\ literature? \\ Yes
}

Are all factual statements correct and adequately supported by citations? 
Yes

Are arguments sufficiently supported by evidence from the published literature? Yes

Are the conclusions drawn balanced and justified on the basis of the presented arguments? Yes

Competing Interests: No competing interests were disclosed.

We confirm that we have read this submission and believe that we have an appropriate level of expertise to confirm that it is of an acceptable scientific standard.

Author Response 29 Jan 2018

Jens Freese, Deutsche Sporthochschule Köln, Germany

We would like to thank all reviewers for their constructive comments and positive feedback to our article. We have addressed their comments as described below, and think that they greatly helped to improve our article further.

The authors have discussed the relationship between the organs and shift in the metabolic flux during the two different lifestyles, hunter and gatherers, and sedentary. The metabolic linkages with circadian rhythm during hunter and gatherers life style, and how it has got disturbed now, are well explained.

However, there are certain points authors may like to connect to make it more explicable. Take an example where the transition of life style was not abrupt, the hunter and gatherers when became agricultural societies and started dwelling in the stable communities with no uncertainty in most of the life activities, and feast and famine were not as frequent. Did the biochemical changes in the metabolism undergo some adaptation to the relatively and progressively 'sedentary life style'? The agricultural societies have now transformed into industrialized societies with modern amenities and energy-rich foods within arm's reach.

A: Thank you for this comment. However, our point was not to imply that early agriculture led to better food security and less famine. In fact, early agriculturalists may have experienced more frequent and more severe periods of famine than huntergatherers due to the latter's higher flexibility to change habitats (Berbesque et al. 2014, Biol Lett 10: 20130853 ). This also questions Neel's thrifty gene hypothesis as we now briefly mention in the revised article. However, the lactase persistence gene and copy number variation in the AMY1 (amylase) gene present examples for rapid biochemical adaptions that, however, only occurred in single genes and do not have a large impact on global physiology.

Evolution indeed is a progressive natural mechanism. Is it possible that the 'thrifty genes' that became advantageous during hunting and gathering era of human existence, has become a sort of burden and will be eventually eliminated from the gene pool? Probably a better adapted gene set, say 'lean genes' to these emerging trends would help humans 
survive the endemic 'modern life style'. Are there any indication of such evolutionary tendencies in humans today? Can the modern tools such as CRISPER-Cas be utilized in near future to modify the so called 'thrifty genes' and to rewire the metabolic flexibility? This is especially important when the evolution depends more on artificial selection than natural!

A: Even if there would be some true aspect to the thrifty gene hypothesis, we think it is very unlikely that evolution would now start to select for "lean genes", for the following reasons: First, while obesity and its related diseases are now occurring more frequently at very young ages already, they are chronic in nature and do not pose a significant risk for dying before sexual reproduction has occurred. Second, modern medicines and pharmaceutical drugs are able to significantly prolong the life of patients with metabolic diseases. However, whether modern tools such as CRISPERCas could be utilized to modify certain "thrifty genes" remains speculative, and we think is beyond the scope of our paper. It would not only presuppose that such genes really exist (our example of uricase is rather unique in its effect on metabolism) but also that modifying these individual genes could reverse or neutralize the effects of an unhealthy lifestyle - which is probably not the case because lifestyle choices affect not individual genes, but have complex effects on the whole genome.

The life, and the metabolism that drives life, are flexible and would therefore evolve an alternate mechanism to handle the pressure of modern life style on human health and survival. What biochemical alternatives or shunts could be suggested to overcome the so called metabolic inflexibility. Authors may have suggested or postulated more credible ways to thwart the metabolic inflexibility than merely propounding 'retrain all prescribed modes periodically', where the term 'periodically' is clearly vague!

A: We now mention pharmaceutical drugs such as metformin or "calorie restriction mimetics" such as resveratrol as possibilities that activate the starvation and foraging pathways (AMPK, SIRT1 etc.), but we think it is beyond the scope of this article to provide a somewhat detailed description of these approaches. Also, we are personally convinced that no single drug is able to fully mimic the complex interplay between molecular pathways that gets activated through lifestyle modifications. We have also removed the term "periodically" and replaced it with some more specific recommendation examples.

At places the authors have mentioned about the satiety signalling, where they state that leptin resistance is a common scenario in the sedentary life style. Is there evidence that the satiety signaling involving leptin and ghrelin have evolved in favour with the progressing inactive lifestyle?

The authors have well explained the brain reward system in feeding behaviour. Modern habits and lifestyle is inclined towards abnormal hedonic behaviour where there is an excessive intake of processed food with high glycemic index and low nutritive value, dissatisfaction to the brain drives such a behaviour leading to obesity. Could authors suggest ways or quote studies where balancing the nutritive value of the food has been attempted such that they regulate the hormonal homeostasis that controls the excessive eating behaviour in individuals? 
Competing Interests: No competing interest.

The benefits of publishing with F1000Research:

- Your article is published within days, with no editorial bias

- You can publish traditional articles, null/negative results, case reports, data notes and more

- The peer review process is transparent and collaborative

- Your article is indexed in PubMed after passing peer review

- Dedicated customer support at every stage

For pre-submission enquiries, contact research@f1000.com 